\title{
PAISAJE, NARRATIVAS Y EXPERIENCIA: LA VIRTUALIZACIÓN DEL PAISAJE MAYA
}

\author{
Rodolfo URiBe INIESTA \\ Programa de Estudios Regionales del Centro Regional de Investigaciones \\ Multidisciplinarias, Universidad Nacional Autónoma de México \\ Visiting Fellow Australian National Centre for Latin American Studies, \\ Australian National University
}

\begin{abstract}
Resumen: El territorio conocido en los últimos 30 años como El Mundo Maya ha sufrido severas transformaciones desde que se le incorporó a la demanda del turismo global. Estos cambios han afectado sobre todo la organización territorial y, de manera importante, a los paisajes e incluso ciudades, playas y zonas arqueológicas. Estos cambios ajustan los emplazamientos, los paisajes y sitios a las expectativas de las narrativas culturales y a la infraestructura, rutas y tiempos del sector turístico. Esto resultó en una organización fractal del espacio donde las principales atracciones turísticas y lugares culturalmente relevantes muestran, cada uno, elementos de todas las narrativas históricas relacionadas con la región en una lógica de parque temático.
\end{abstract}

Palabras Clave: estudios culturales, Mundo Maya, narrativas culturales, orden fractal, turismo.

ABSTRACT: The territory defined in the last 30 years of the twentieth century as The Mayan World has suffered a severe transformation since it has been incorporated to the main world touristic demand. Changes mostly are related to territorial organization, and most important to landscape and even cities, beaches and archeological sites. This changes adjust the places, the landscapes and sites to the expectations of the cultural narratives and infrastructure, routes and times of the touristic sector. This has resulted in a fractal organization of space where the main touristic and cultural meaningful emplacements show each one of its elements of all the regional related historic narratives in a thematic park logic.

Kerwords: Cultural Studies, Mayan World, Cultural Narratives, Fractal Order, Tourism.

RECEPCIÓN: 22 de febrero del 2011.

ACEPTACIón: 23 de mayo del 2011. 



\title{
PAISAJE, NARRATIVAS Y EXPERIENCIA: LA VIRTUALIZACIÓN DEL PAISAJE MAYA
}

\author{
Rodolfo URIBE INIESTA \\ Programa de Estudios Regionales del Centro Regional de Investigaciones \\ Multidisciplinarias, Universidad Nacional Autónoma de México \\ Visiting Fellow Australian National Centre for Latin American Studies, \\ Australian National University
}

\section{Introducción}

En este artículo describimos, desde la perspectiva y metodología de los estudios culturales, cómo la incorporación de los imaginarios turísticos construidos sobre los discursos de lo maya y los mayas, y sobre pasajes de historia del sureste de México (particularmente la península de Yucatán), ha guiado la reformulación de espacios y conjuntos culturales arqueológicos, naturales y urbanos, y de hecho de toda la organización territorial de esta región. Esta reorganización, en tanto considera un tipo de turismo de acceso puntual y tiempo limitado, ha venido a constituirse poco a poco en una organización de forma fractal donde cada lugar reproduce — como en un holograma - la totalidad de información del espacio y un conjunto de elementos semejantes en cada sistema particular. Así, el proceso histórico de la región queda reducido a una narrativa mínima, y los espacios también aparecen como compartimentos especializados reconstruidos, minimalísticamente, en medio de lo que antes fue el verdadero paisaje maya y ahora es meramente un espacio indefinido de naturaleza destruida y alterada, zonas de cultivo abandonadas o colonias y pueblos empobrecidos.

Las personas acostumbraban viajar para conocer y experimentar la vida de otra gente y paisajes ignotos, extraños: sus sistemas culturales y socioproductivos. El viaje arquetípico, incluso iniciático, era desde un lugar establecido como central, como lo civilizado, lo rutinizado, lo controlado, hacia lo salvaje, lo incontrolado, lo extraño, la naturaleza. Esto ocurría desde las culturas primarias (Eliade, 1998) hasta el discurso romántico con su lógica de "perderse para encontrarse" descrita y razonada como nadie por Johannes Wolfang Goethe en su tragedia Fausto.

Respecto a México, tanto Europa como Estados Unidos han mantenido esa particular expectativa, lo cual puede descubrirse en obras de principios del siglo xx como las de los autores ingleses D.H. Lawrence (The Plumed Serpent), Graham Greene (Lawless Roads) y Malcolm Lowry (Under the Volcano).

Advertimos incluso en personajes menos relevantes esta perspectiva: así, Ann Sengher (1975), ante la perspectiva de obtener en Marsella una visa para México y huir de los nazis, a pesar del apremio reflexionaba: "Si el otro lado realmente 
era la naturaleza salvaje que le regresa la juventud a todo y a todos, lamentaría después no irme con ellos".

Esta expectativa tiene mucho que ver con las ideas respecto a los grados y formas de sometimiento de la naturaleza, ya sea directamente como elementos geográficos y ecológicos, y de la gente local y su cultura identificadas como nativas o naturales. Así, desde la perspectiva científica, los editores de un proyecto inglés de historia mundial de 1933 lo expresaron de una manera muy directa:

El conocimiento del proceso mediante el cual Norte América fue descubierta y gradualmente saturada con Europeos es la base necesaria para entender las reacciones modernas entre el continente nuevo y el viejo. En Sud América se está viendo trabajar el mismo proceso, aunque todavía incompleto porque la Naturaleza todavía no ha sido sometida (V.T. Harlow y J.A. Williamson apud Newton, 1933).

La perspectiva se justifica incluso ahora. En nuestros días, cuando desde un país del tercer mundo como México se visitan los parques naturales de países de colonización inglesa como Canadá, Estados Unidos, o incluso de lugares lejanos como Australia (lo mismo uno cercano a la capital Canberra como Tindinbilla, o los "lejanos" y "arcaicos" en tierras reconocidas a los aborígenes como Lychfield o Kakadu, en el Northern Territory), se siente la incomodidad de un escenario con una naturaleza demasiado "sometida", ordenada. Fácilmente uno reconoce el sentido en que la industria del turismo globalizado está cambiando nuestros paisajes naturales para ofrecerlos a la comercialización. Así, por ejemplo, la imagen urbana del centro de una ciudad que desde Europa, Estados Unidos o incluso las grandes ciudades del oriente australiano es vista como lejana y exótica, Darwin (capital del Northern Territory), es abrumadoramente similar a la imagen que se tiene de California o Florida: incluso puede sentirse un deja vú respecto a Playa del Carmen en el Caribe mexicano por su calle 5 ("La 5"a ") convertida en mall a cielo abierto. Idea de calle-mall, que en nuestro sureste se ha convertido ya en arquetipo con significación simbólica cultural al grado de que la principal revista de noticias sociales y publicidad de la región se llama La Quinta. Dicho concepto se convierte en modelo a reproducir al reformular centros urbanos, como ocurrió en el 2011 en la antigua Zona Luz de Villahermosa.

Este último proceso es el que quiero señalar: el de la reformulación de la realidad material a partir de una narrativa inspirada en un estado de no control, "natural", que termina siendo un imaginario virtual, el cual con su supuesta "pureza" se impone para modificar la realidad social-histórica "real" o "natural”. Dicho fenómeno se nos impone ahora con toda su fuerza mediante los imaginarios impulsados por los medios electrónicos de comunicación. Así, por ejemplo, hoy en la televisión mexicana se anuncia como una tradición indígena "recuperada" el viaje por sal entre la isla de Cozumel y el antiguo puerto de Polé, hoy Parque Temático Xcaret, que realizaban los itzáes prehispánicos. Desaparece la historia real y las condiciones reales actuales del pueblo sobreviviente. 
Luego entonces el simple hecho de ir a otra parte se ha complejizado en el mundo contemporáneo porque es un viaje motivado, impulsado, a través de densas cortinas de narrativas, imágenes diríamos. Incluso podemos rescatar tanto el sentido moderno de proyección en pantalla plana al que se refería Jean Baudrillard (2000), como el complejo integral de forma de pensamiento considerado desde Eliade (1998), hasta la idea de imaginario usada por Jean Paul Sartre (2006).

Pero esto está mediado ahora por una particular condición sicológica del consumidor que tiene efectos económicos, los cuales a su vez se traducen en iniciativas de reformulación tanto paisajística como social. Esta condición es una particular intolerancia a la frustración. El viajante se coloca frente al viaje (de hecho, frente a los ofertantes turísticos de pasajes, alojamiento, etc.) como consumidor, y en tal condición exige obtener lo que busca basado en su preconcepción formulada por la narrativa anteriormente consumida, aunque eso no coincida con la condición del hecho local. El viajero-consumidor es ahora un niño incapaz de absorber/confrontar/aceptar información totalmente externa a su imaginario (determinado por una narrativa anterior exótica), y sin tolerancia a la frustración.

Y esta condición está en el extremo del inicio del viaje, en el origen del viaje. Está, a su vez, condicionada - tanto esa necesidad imperiosa de viajar lejos y al lugar más exótico de su imaginación, mejor si geográficamente alejado, como la capacidad negada de experimentar lo externo, lo inesperado, lo no ya imaginado- por lo que Anthony Giddens (1991) llama "el secuestro de la experiencia".

Este artículo presenta avances de una investigación en marcha de los procesos que están ocurriendo en el lado mexicano de lo que las agencias internacionales de planeación regional llaman Mesoamérica, y que las instituciones culturales y turísticas llaman El Mundo Maya, que al mismo tiempo se conoció en el siglo xx mexicano bajo el cronotopo de El Sureste. El concepto de Mihail Bajtín (1989) de cronotopo se refiere a una idea holística que nos remite a un lugar y tiempo particular considerado como un conjunto identificable en el espacio de un contexto cultural determinado. De esta manera funcionaba para los mexicanos la idea de El Sureste que abarcaba la parte tropical oriental del país, incluyendo a la península de Yucatán, la cual de hecho está a la misma latitud que la ciudad de México. En este capítulo me centro en los procesos relacionados con la costa oriental de Quintana Roo, ahora renombrada Riviera Maya, para describir cómo los elementos culturales de la civilización maya son usados con el fin de alcanzar una reconstrucción y reorganización del espacio, reemplazando los paisajes y la ecología y sociedad locales.

En este artículo demuestro cómo la Riviera Maya, todo el estado de Quintana Roo, y aparentemente de manera progresiva todo el espacio y territorio considerado como El Mundo Maya, está siendo reconfigurado y reorganizado bajo una lógica fractal que tiene como idea guía o "atractor de orden" (en concordancia con la teoría del caos) tanto las necesidades del viaje de larga distancia desde las metrópolis europeas y estadounidenses como el ya discernible modelo estético del producto cultural posmoderno llamado Xcaret. 


\section{La reducción del mundo}

¿Qué es lo que usualmente ve un visitante en El Mundo Maya? Aquí, con su autorización, uso como ejemplo lo que una turista lituana (la cuñada de mi sobrino) subió al Facebook para compartir con su familia y amigos. La idea es que el álbum funciona como una representación social de acuerdo con el concepto de Denise Jodelet (1993), en tanto se ha realizado una selección y resumen de lo que quería mostrar, compartir y conservar como memoria del viaje (figuras 1, 2 y 3).

Como puede verse, los lugares en donde se toman las fotos (aún cuando supuestamente son escenarios naturales) son jardines diseñados. Incluso el cenote es ahora un área controlada, modificada, segura (quizá la palabra adecuada sería el horrible neologismo "securitizada") y administrada. La presencia de las estructuras arquitectónicas mayas, a su vez, aparecen reducidas meramente a escenarios. Y, como puede verse en la mayor parte de las fotos, fueron tomadas en los interiores de hoteles de diseños minimalistas. Excepto por el sitio arqueológico, no hay lugares públicos en las fotos.

\section{La experiencia del todo incluido}

Veamos ahora tres experiencias representativas del turismo corporativo.

La versión México-caribeña de El corazón de las tinieblas:

Todavía en 1993, cuando se visitaba Chetumal, Quintana Roo, al llegar al final del malecón en el sur se encontraba un pequeño restaurante frente a una reja tras la cual se veían tupidos manglares. Se decía la última esquina de México, una especie de fin del mundo civilizado, porque se suponía que detrás estaba la selva y Belice. Ahora, donde estaban los manglares, y aún en el lado mexicano de la frontera, hay un centro comercial, un hotel posmoderno sellado con ventanas reflejantes y, junto al mar, una construcción tipo casa colonial británica desde donde parten las excursiones en búsqueda de manatíes. Para la excursión los turistas abordan unas cómodas lanchas de fondo plano y se sientan en enormes sofás blancos que remedan una lujosa sala al estilo del Miami de la serie televisiva Miami Vice. Después de recibir excesivas indicaciones de seguridad, el bote navega hacia la entrada del río Hondo, que es la verdadera frontera entre ambos países. En la desembocadura se pasa una hora observando toda clase de aves en los árboles de una isla, y eventualmente se ve el lomo o las narices de algunos manatíes. Luego el bote sube por el río por media hora avanzando a través de una diversidad de ecosistemas naturales como petenes, pantanos y selvas. Los turistas escuchan largas explicaciones sobre la ecología e historia locales que provocan la sensación de estar viajando hacia atrás en la flecha del tiempo y de 

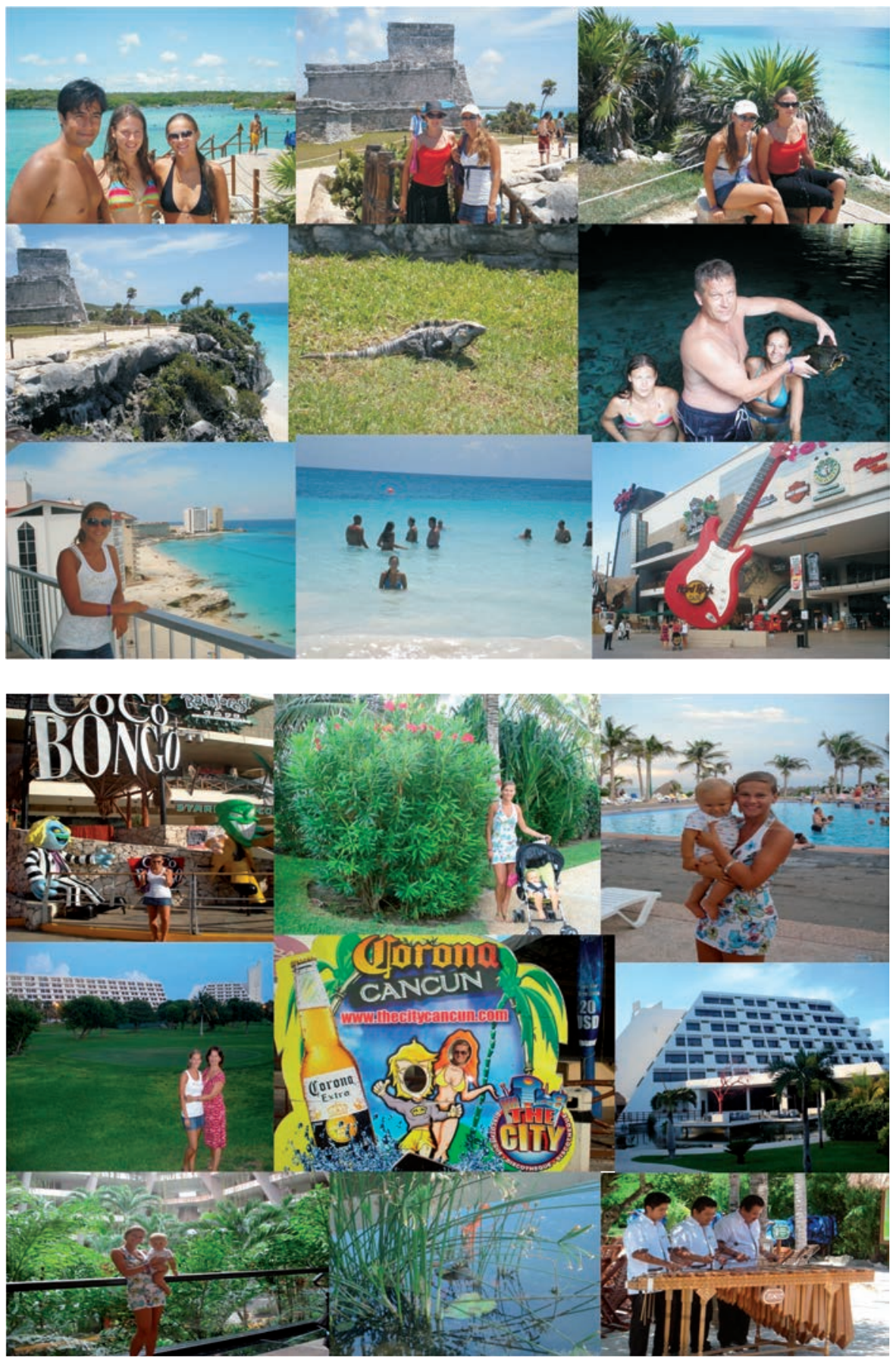

FiguRAs 1 y 2. Fotografías realizadas por una turista liltuana en la Riviera Maya. Tomadas con su autorización de su página de Facebook 


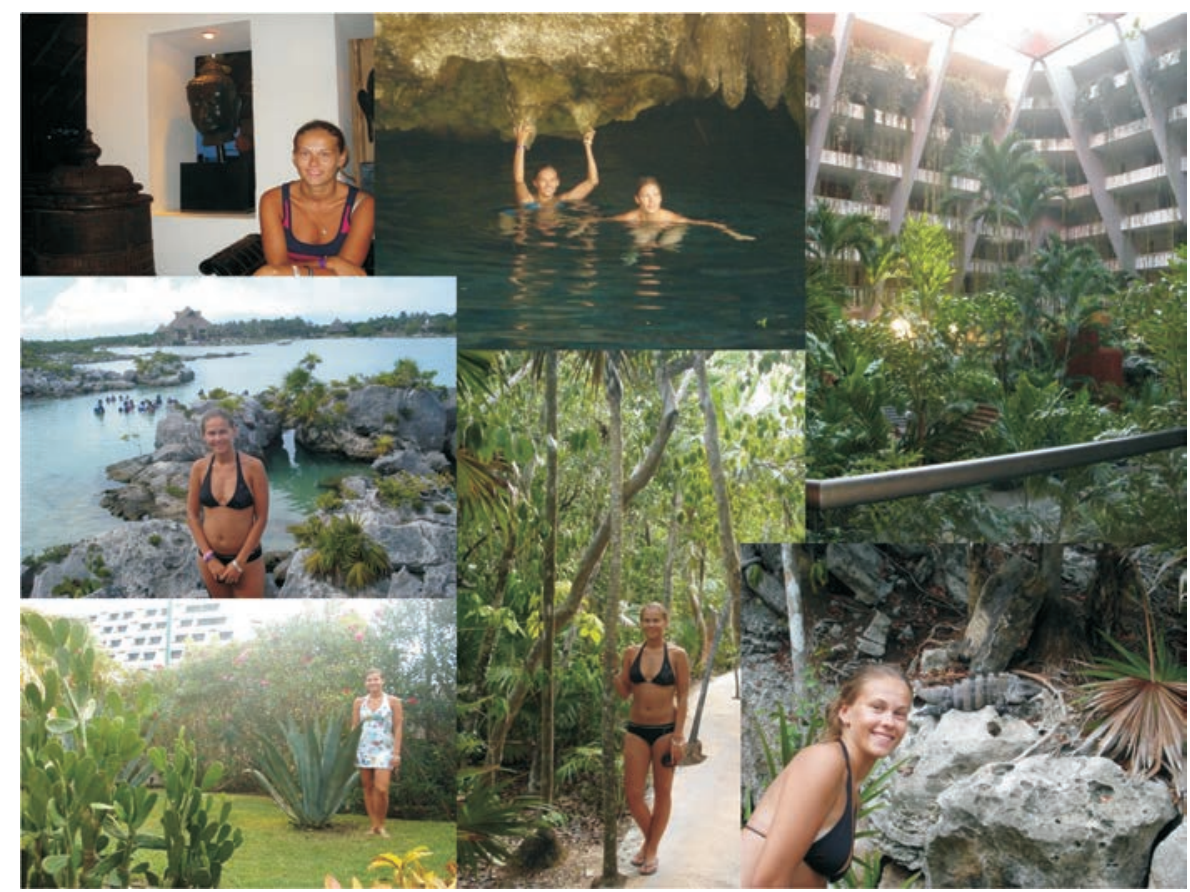

FiguRA 3. Fotografías realizadas por una turista liltuana en la Riviera Maya. Tomadas con su autorización de su página de Facebook

la sucesión ecológica, hacia lugares más primordiales y primitivos en contraste con el posmodernismo del embarcadero (figuras 4, 5 y 6).

Pero entonces, al final de la jornada, surge el verdadero corazón de las tinieblas: bajo el puente Subteniente López la lancha da la media vuelta y los turistas pueden ver las pequeñas cañoneras de la armada mexicana de un lado; del otro, en Belice, tras una reja, los casinos, bodegas y tiendas de la zona libre de impuestos. La modernidad y toda su decadencia con un aspecto igual al de las colonias comerciales populares del Distrito Federal (figuras 7 y 8).

\section{1) La ilusión ecológica: el espejismo de El Blanquizal}

Justo al sur de Tulum comienza la más importante reserva natural mexicana. La Reserva de la Biosfera de Si'an Ka'an (en maya) o Siankán (hispanizada). Incluye selvas, pantanos, manglares, varias lagunas continentales, otra costera y dos espléndidas bahías, además de parte de la segunda mayor barrera de coral del mundo (con la particularidad de que la barrera está realmente cerca de la costa y a no más de 3 metros de profundidad). En contraste, al norte de Tulum comienza un corredor comunicado por una supercarretera de seis carriles que incluye más 

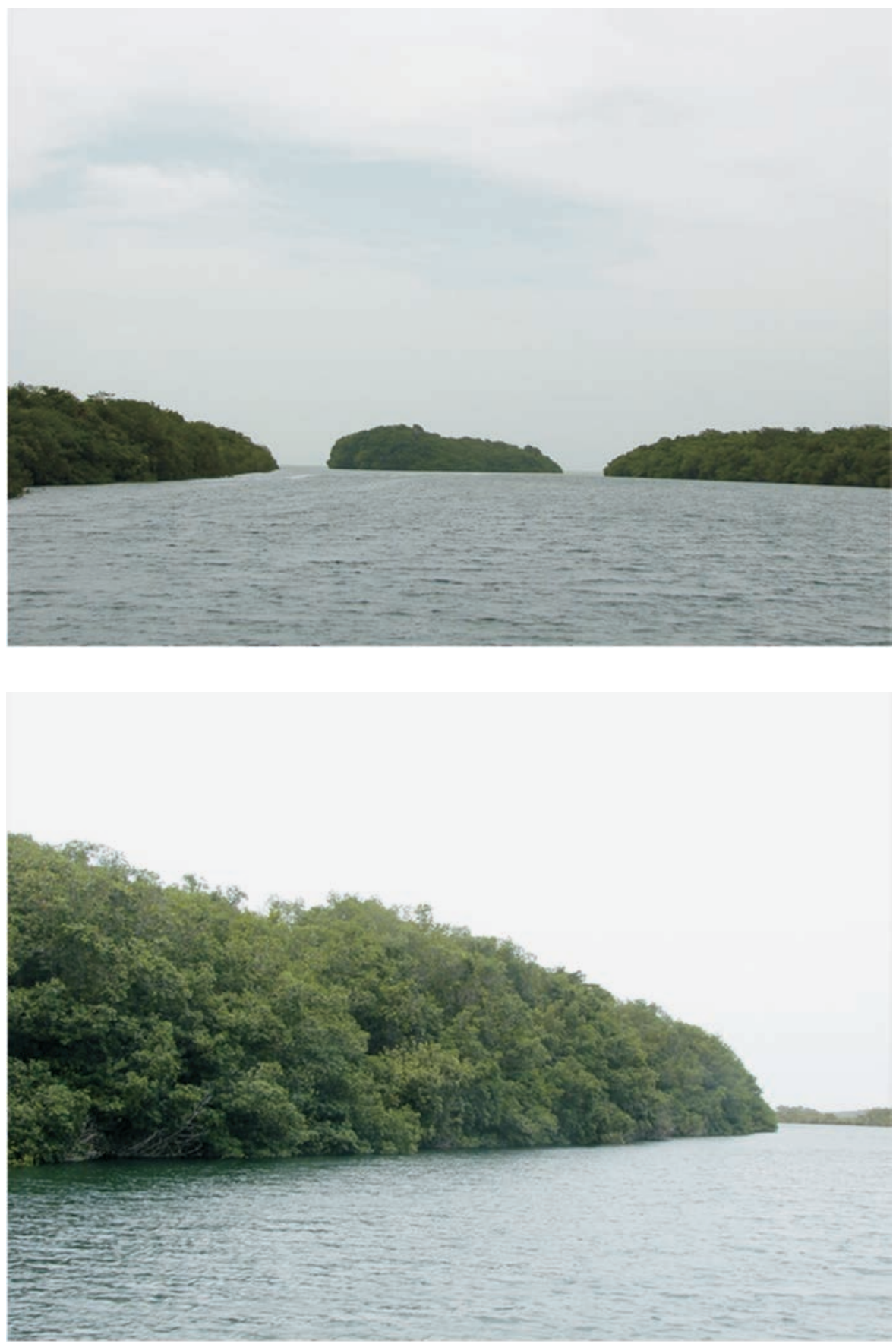

Figuras 4 y 5. Imágenes de río Hondo 


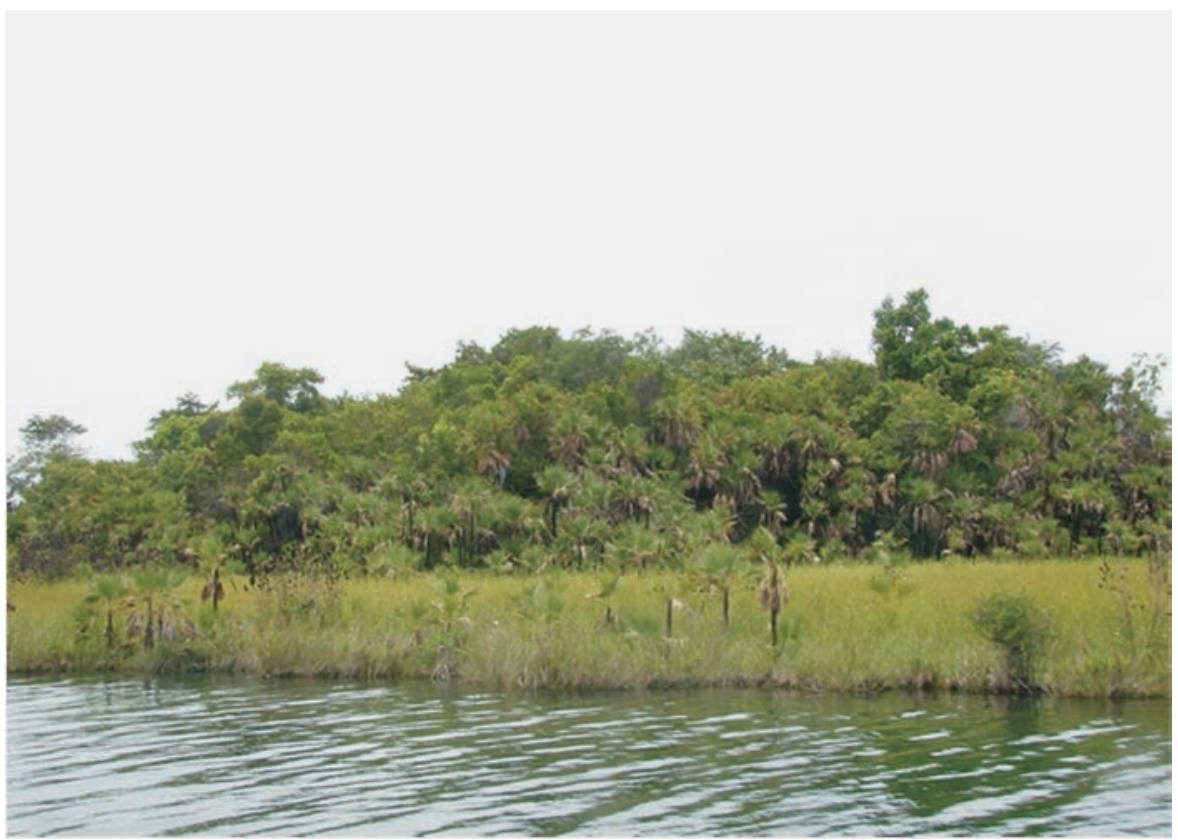

Figura 6. Imagen de río Hondo

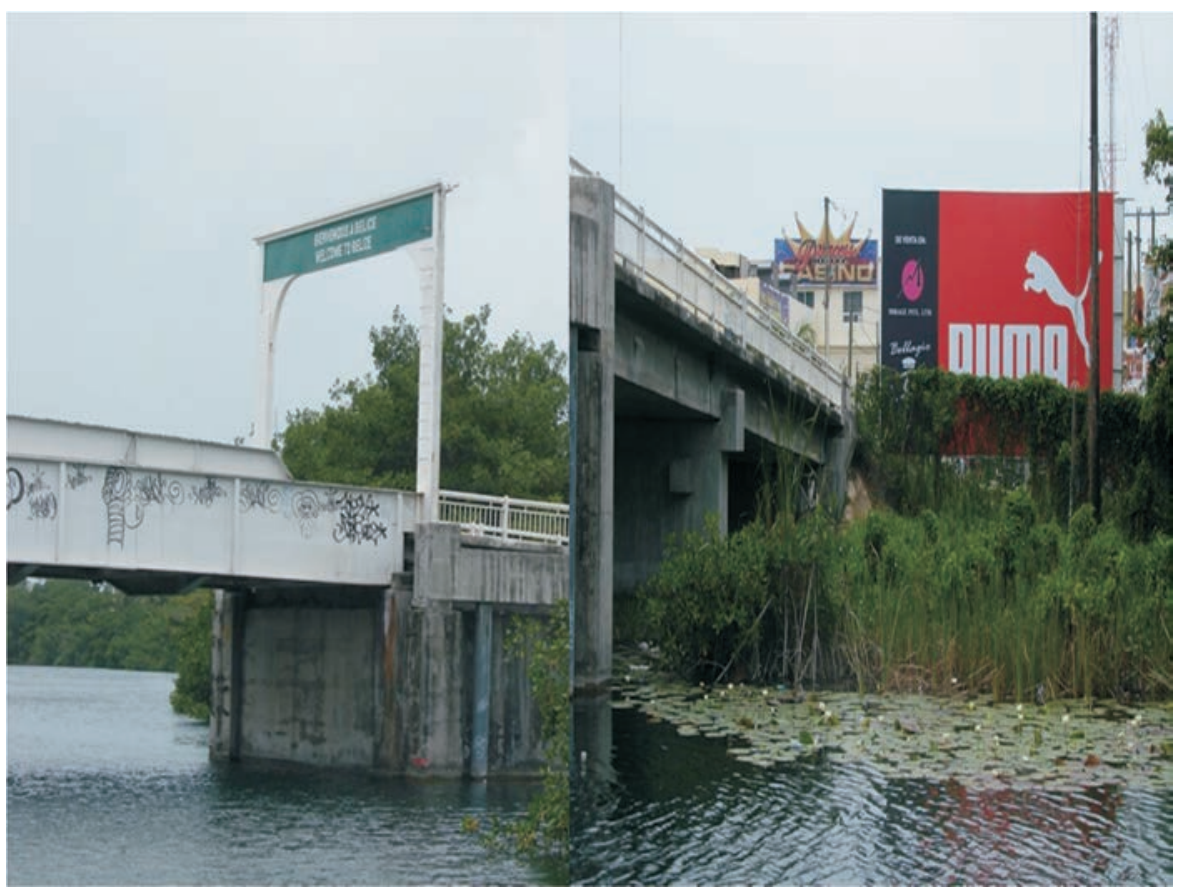

Figura 7. Frontera entre México y Belice 


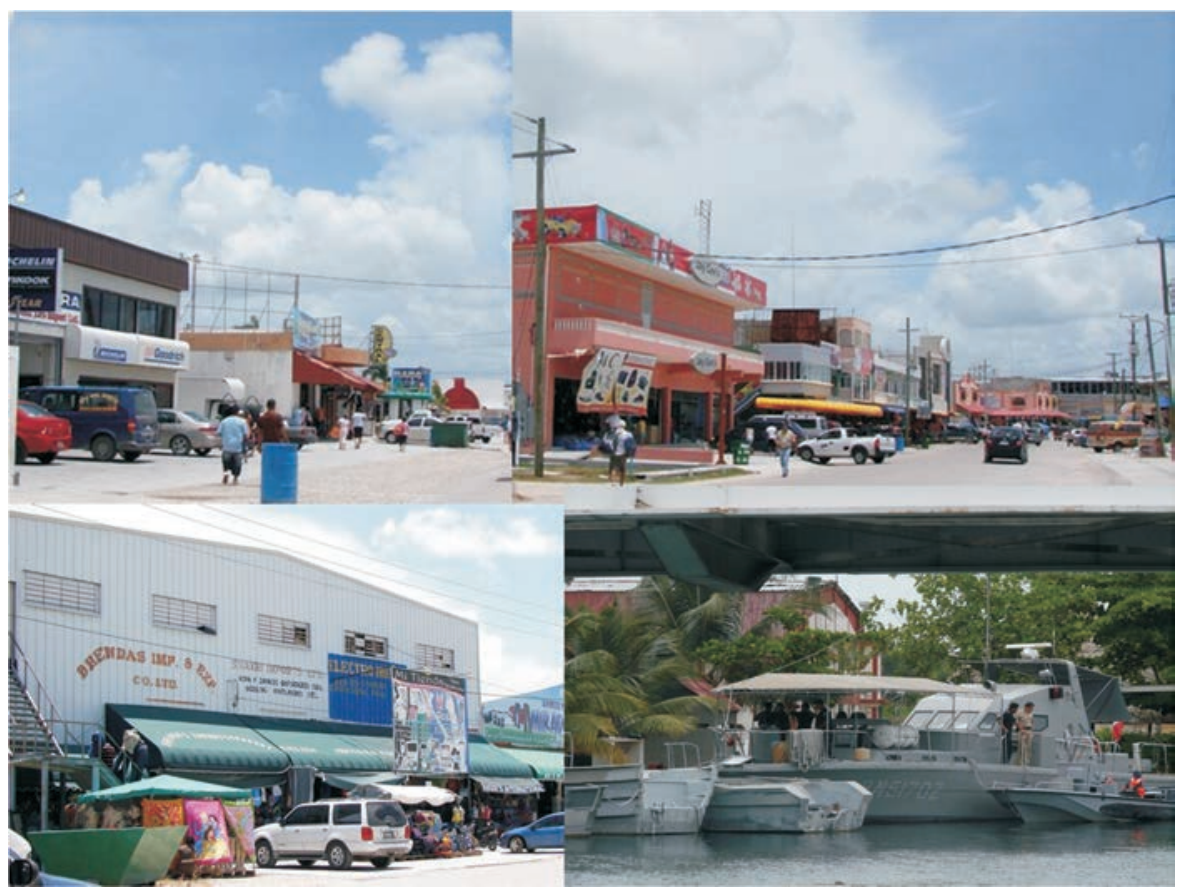

Figura 8. Zona libre de Belice

o menos 30 hoteles todo incluido, cuyo mapa actual reproduce la visión que en los años 70 tenía un atlas de zonas arqueológicas en la misma zona.

Tulum en sí mismo no era sino hasta hace algunos pocos años un pequeño pueblo con casas de un piso, separado de sus más bien artificiales playas de arena y sus (ya en los 90) costosos hoteles naturistas, por un gran espacio preservado de selva. Era el lugar donde el turismo amante de la naturaleza y de la cultura huían del estilo y los precios miamitas de Cancún y Playa del Carmen. Ahora, la reserva natural que era patrimonio de la Universidad de Quintana Roo ha sido arrasada para construir un fraccionamiento de hiperlujo: Villa Zamá. Al mismo tiempo se erigió el pueblo en un nuevo municipio, separándolo de Playa del Carmen, y se construye un nuevo aeropuerto para darle acceso directo al turismo que antes tenía que pasar por Cancún.

Además de anidar una de las más conocidas y fotogénicas zonas arqueológicas, Tulum es ahora la puerta de entrada a Si'an Ka'an. Para llegar a esta reserva desde los hoteles todo incluido hay que recorrer 60 kilómetros de una carretera costera de terracería.

El objetivo principal del viaje es hacer el tour marino de la bahía de la Ascensión donde es muy fácil observar delfines, tortugas, estrellas marinas y pescados y snorkelear en el arrecife de coral. En el recorrido, al final, la gente es llevada a un bajo de arena llamado El Blanquizal, donde los turistas bajan directamente 
al mar a nadar en una zona muy baja, sin necesidad de llegar a tocar la deslumbrante arena blanca de la playa (figuras 9, 10 y 11).

Normalmente por la mañana esta carretera está tomada por caravanas de jeeps organizadas por los hoteles todo incluido, o por jeeps aislados rentados en los mismos hoteles por gente que, según sus palabras, busca escapar de los pabellones y restaurantes temáticos representativos de las regiones mexicanas (que normalmente constituyen el orden interno de estos hoteles), para conocer "la verdadera selva, el verdadero México" (figura 12).

Pero si va uno por su cuenta a Punta Allen, el punto de embarque, no podrá hacer nada, porque no sólo los viajes conducidos por las cooperativas de exlangosteros, sino todas las comidas de los pequeños restaurantes están ya apartadas por las corporaciones turísticas. Viajar por cuenta propia significa ver otro mundo. Los mismos lancheros podrán indicarle cómo llegar a la más hermosa playa, El Blanquizal, otra vez: pero en esta ocasión la indicación es el kilómetro 5, ahí donde en el 2007 podía encontrarse un coche quemado en una escaramuza de narcotraficantes. Y entrando desde la carretera en ese año había que atravesar una extensión de al menos 10 metros de desperdicios y basura antes de llegar a la arena blanca. Razón por la cual los turistas son bajados de las lanchas en el mar, desde donde la basura se confunde con la línea de vegetación bajo las palmeras. De hecho, parando en las diversas playas, uno encontraba ese año basura en todas partes y podía informarse de que las casas, todavía semidestruidas por el huracán Dean, eran en su mayor parte propiedad de los grandes potentados mediáticos mexicanos, o de conocidos narcotraficantes mexicanos y colombianos: por ello tampoco sorprendía encontrarse con patrullas de soldados (figura 13 y 14).

Así que, aparentemente, las reglas de conservación de la reserva sólo tienen vigencia en los espacios turísticos y El Blanquizal es, como aparece mientras se acerca uno desde el mar, un espejismo.

De una manera menos dramática la misma desilusión se sufre con lo que se presenta como ecoturismo en la mayor parte de los lugares de la región. Por ejemplo, en la entrada de la zona arqueológica de Calakmul se encuentra uno de los más hermosos y sencillos ecohoteles de la zona, rodeado de una densa barrera de árboles delgados como bambús. Pero si uno atraviesa esa barrera no se encuentra con la selva sino con milpas. Y cuando uno contrata una excursión para observar aves, es posible encontrar una variedad de ellas, algún mono araña como los que viven en un rancho cercano (donde rentan espacio para tiendas de campañas y cuartos rústicos en un entorno de campesinos locales), pero no va a encontrar árboles de más de 60 centímetros de diámetro ni entresijos de lianas, ni los demás elementos que caracterizarían una verdadera selva: se trata de una zona de explotación maderera de los años 70 en recuperación.

Más evidentes son los casos de las "veredas ecológicas" de zonas arqueológicas que casi siempre son zonas de vegetación joven en lugares tan distintos como Dzibilchaltún o Copán. Ahí, donde todavía hay selva antigua o al menos acahual, como en Palenque, si uno recorre las veredas ecológicas hasta sus lími- 

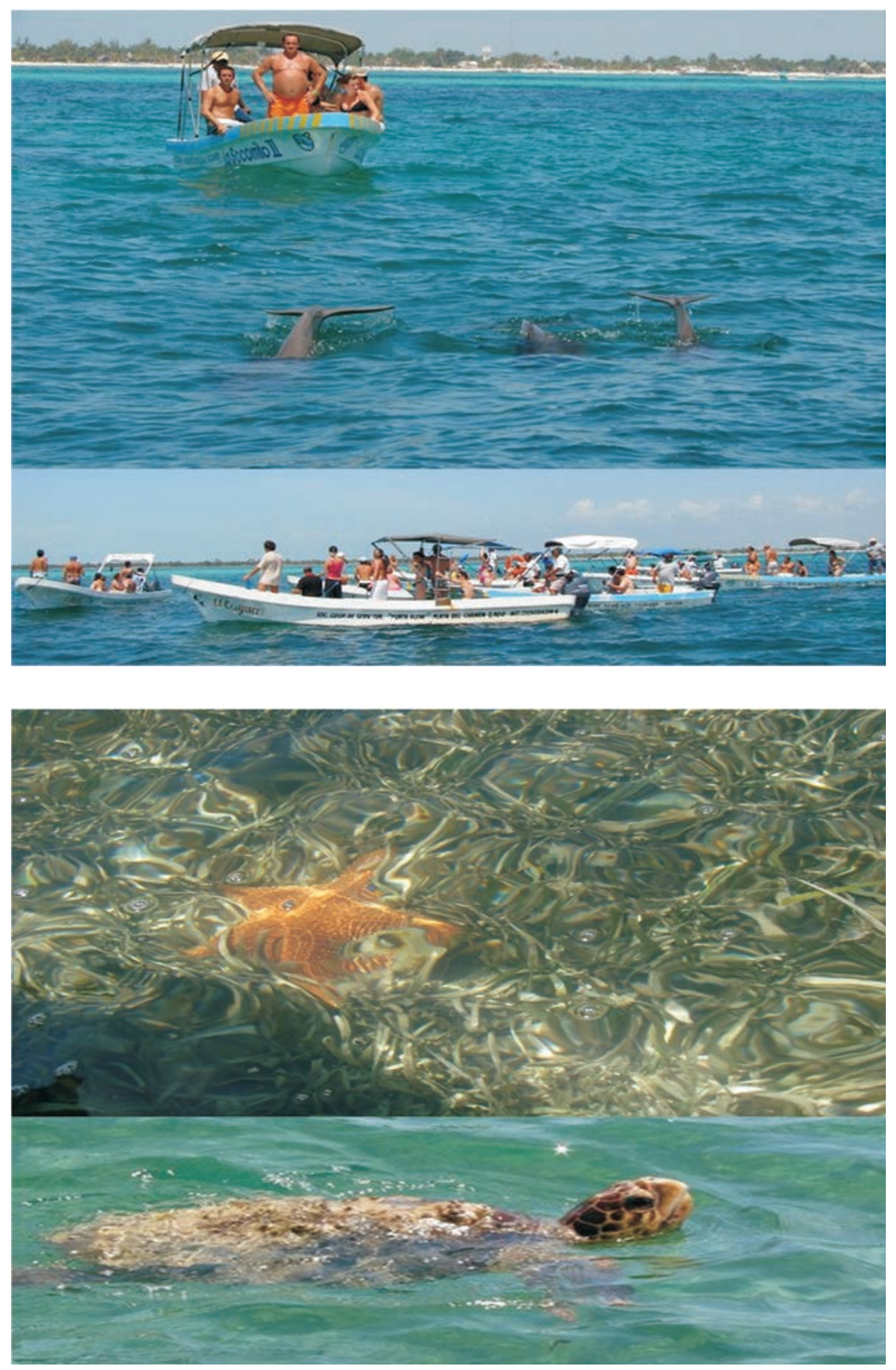

Figuras 9 y 10. Imágenes de El Blanquiazul 


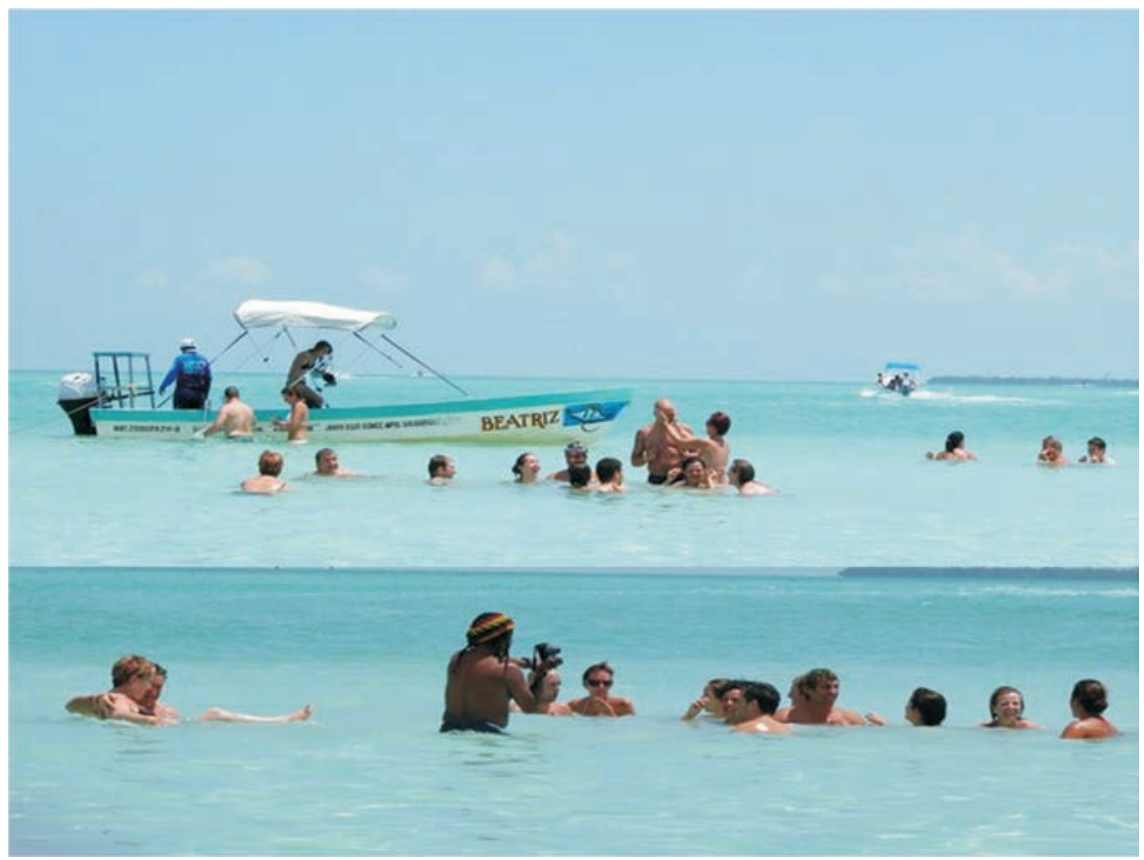

Figura 11. Imagen de El Blanquiazul

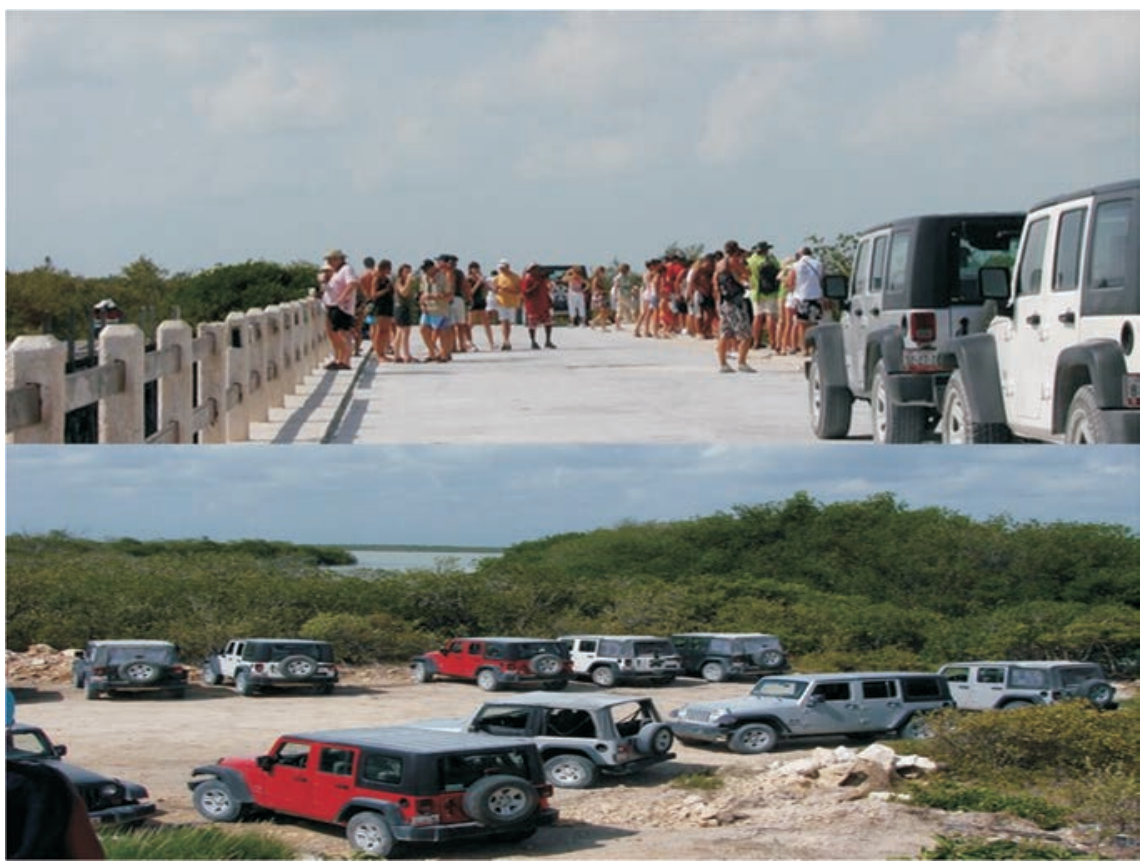

Figura 12. Camino hacia la reserva Si'an Ka'an 

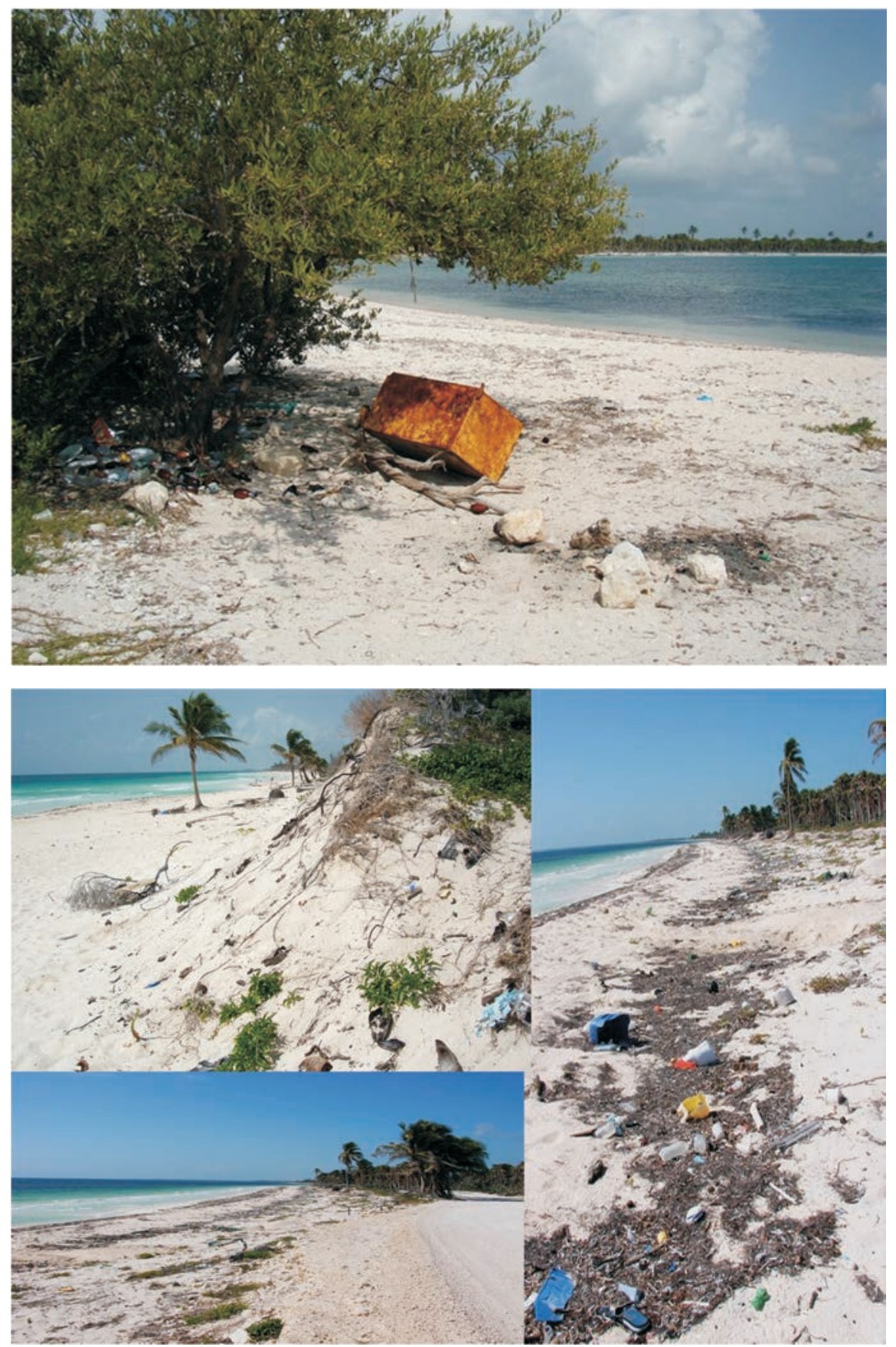

Figuras 13 y 14. Entradas vía terrestre a El Blanquiazul 
tes, se encuentra arriba, en el cerro, el caserío de un ejido; y abajo, en el llano rodeado por el paisaje verde pero plano y de escasa vegetación, los potreros ganaderos. Lo mismo pasa con las húmedas y arboladas barrancas donde se asientan las cascadas de Agua Azul y de Mukul Ha, manteniéndose, en contraste, un paisaje no limitado en Agua Clara, casualmente manejado por una comunidad del Ejército Zapatista de Liberación Nacional.

Así que en el Mundo Maya da la impresión de encontrarse dentro de los estrechos escenarios de un videojuego, fuera de los cuales la naturaleza ha sido devastada. Acudiendo a la memoria, pareciera que hasta los años 70 la naturaleza limitaba los lugares accesibles para su visita por su dominio, pero ahora estamos en un proceso de mantener una escasez de lugares sombreados, húmedos y bellos que se redefinen como recursos en el sentido económico.

\section{2) Actuando el pasado: la hacienda de Sotuta de Peón}

Desde Mérida uno puede contratar cómodos tours a las viejas haciendas henequeneras. La mayor parte de ellas han sido transformadas en exclusivos hoteles y restaurantes, y en muchos casos son propiedad de grupos financieros, principalmente el del viejo Banco Nacional de México, ahora Citibank. De esta manera ahora las haciendas se identifican directamente con las personalidades relevantes del neoliberalismo mexicano, quienes además gustan de hacerse visibles mediante sus políticas de responsabilidad social instalando talleres y tiendas de artesanías donde se autopromueven mediante sus fundaciones caritativas, como ocurre en el centro de Izamal.

En Sotuta de Peón, un grupo de inversionistas organizó una representación de las viejas actividades, interesante porque implica la característica hologramática, la cual, siguiendo a Xcaret, está imponiéndose en cada lugar turístico. Es decir, no se quedan con la presentación de las acciones, hechos, historias y tiempos que caracterizan al lugar, sino que lo usan como soporte para narrar, presentar, proyectar, evocar la mayor cantidad posible de mundos o hechos posibles relacionados con la península.

En el tour uno es recibido inicialmente en la Casa Grande donde rodeado de los viejos mobiliarios uno es informado de la Guerra de Castas del siglo xIX, que en sus momentos más álgidos fue anterior al auge henequenero y luego se mantuvo latente más al oriente de la zona de las haciendas. Después, con las inevitables contradicciones y los matices personales del guía, se narra el auge henequenero y el papel de los grandes propietarios como constructores de la ciudad de Mérida, y la reacción de la Revolución mexicana para acabar con el régimen de esclavitud y los esfuerzos por establecer otro orden basado en los ejidos y finalmente en una empresa centralizada, hasta que se acabó la demanda (figura 15).

Luego, en el patio, se muestran a los turistas las tres etapas técnicas históricas de la producción de la cordelería de henequén, desde el artesanal semimanual, 


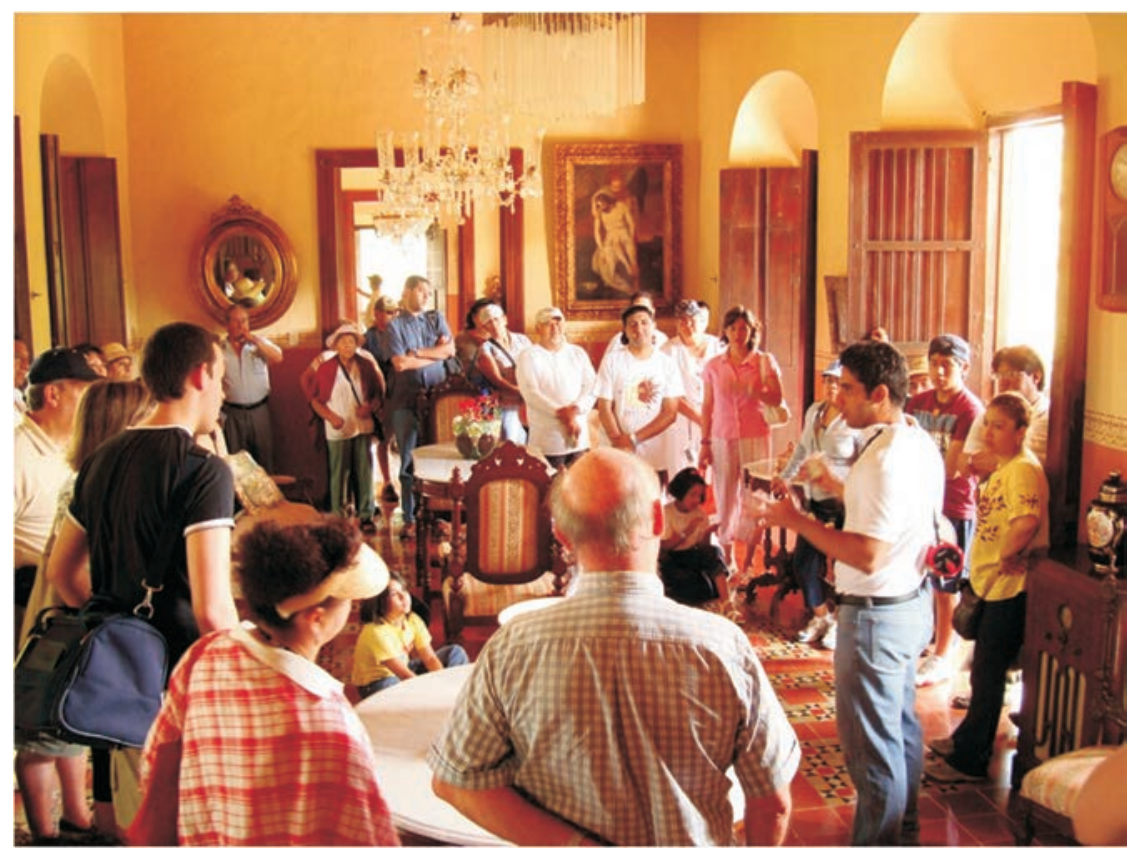

Figura 15. Explicación de un guía en la hacienda de Sotuta de Peón

hasta las modernas máquinas industriales de los últimos tiempos, donde ahora se produce material para artesanías turísticas. En el taller conoce uno al último mecánico sobreviviente de los tiempos de producción industrial, con quien uno puede platicar y tomarse fotos (figura 16).

Después, todavía en el mundo del henequén, los turistas abordan los viejos y grandes carros jalados por caballos que circulan sobre rieles, llamados trucks (que servían antes para transportar el henequén de los campos al taller), para recorrer los campos sembrados todavía de plantas de henequén. Sorpresivamente, el viaje se detiene frente a una pequeña colina donde hay una pequeña casa tradicional maya. Ahí aparece un señor que se dice verdadero maya, y comienza a mostrar un patio y una casa maya tradicionales y a explicar la vida de los campesinos indígenas enseñando algunas palabras mayas, al mismo tiempo que presume palabras de muchos idiomas que le han enseñado los turistas. Después de esta visita al mundo indígena, los visitantes son llevados a un cenote, donde vuelven a encontrarse con Yucatán como un lugar de naturaleza abundante y pueden nadar por una hora (figuras 17, 18, 19 y 20).

\section{De la evocación a la proyección}

¿Qué es lo que permite el funcionamiento y el atractivo de ésta dinámica? Una transición del proceso de evocación al de proyección. Todo el discurso de lo 


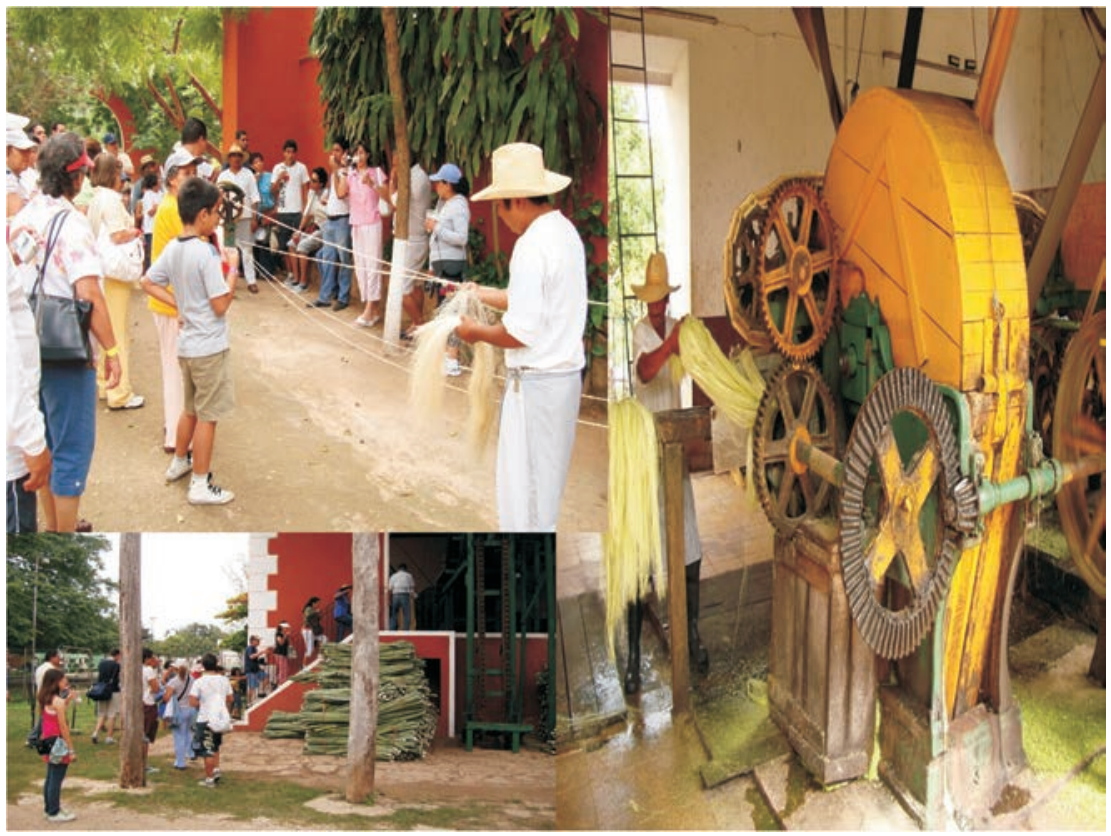

Figura 16. Taller de producción de fibra de henequén en la hacienda de Sotuta de Peón

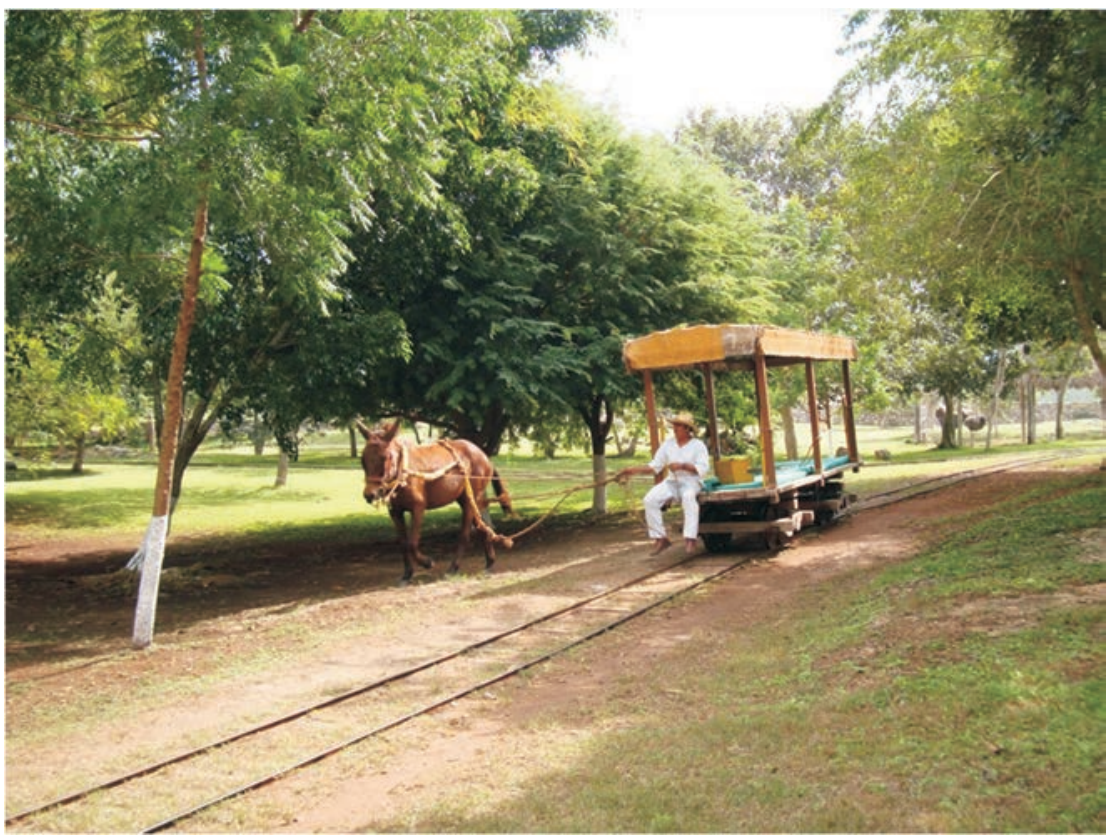

Figura 17. Truck en la hacienda de Sotuta de Peón 


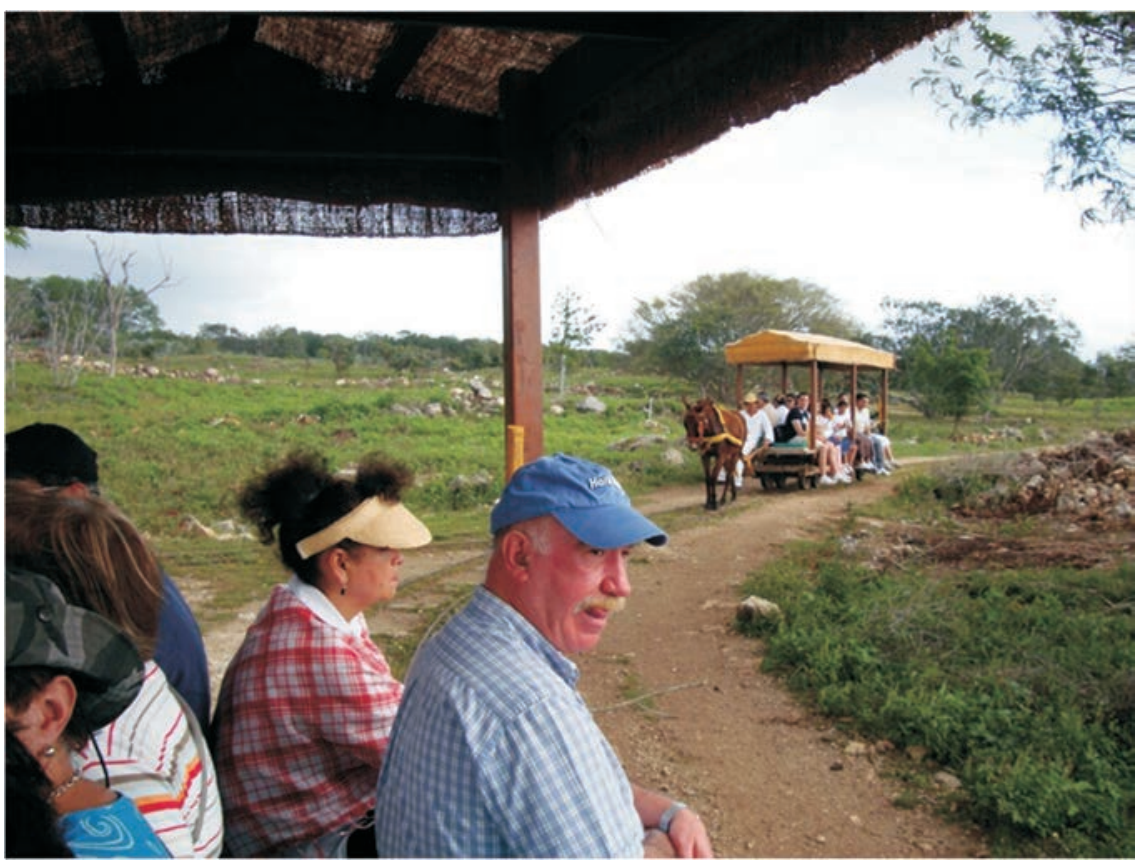

Figura 18. Paseo en truck por la hacienda de Sotuta de Peón

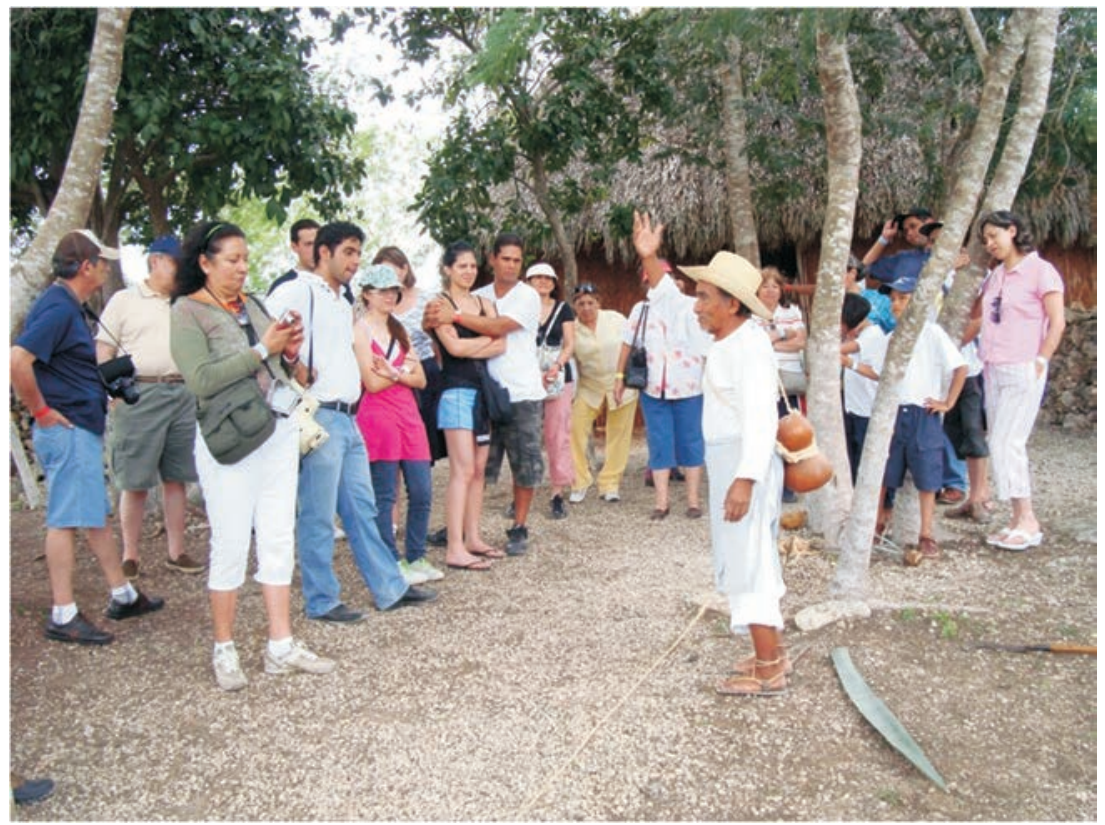

Figura 19. Descripción de una casa y un patio tradicionales por parte de un indígena maya a los turistas en la hacienda de Sotuta de Peón 


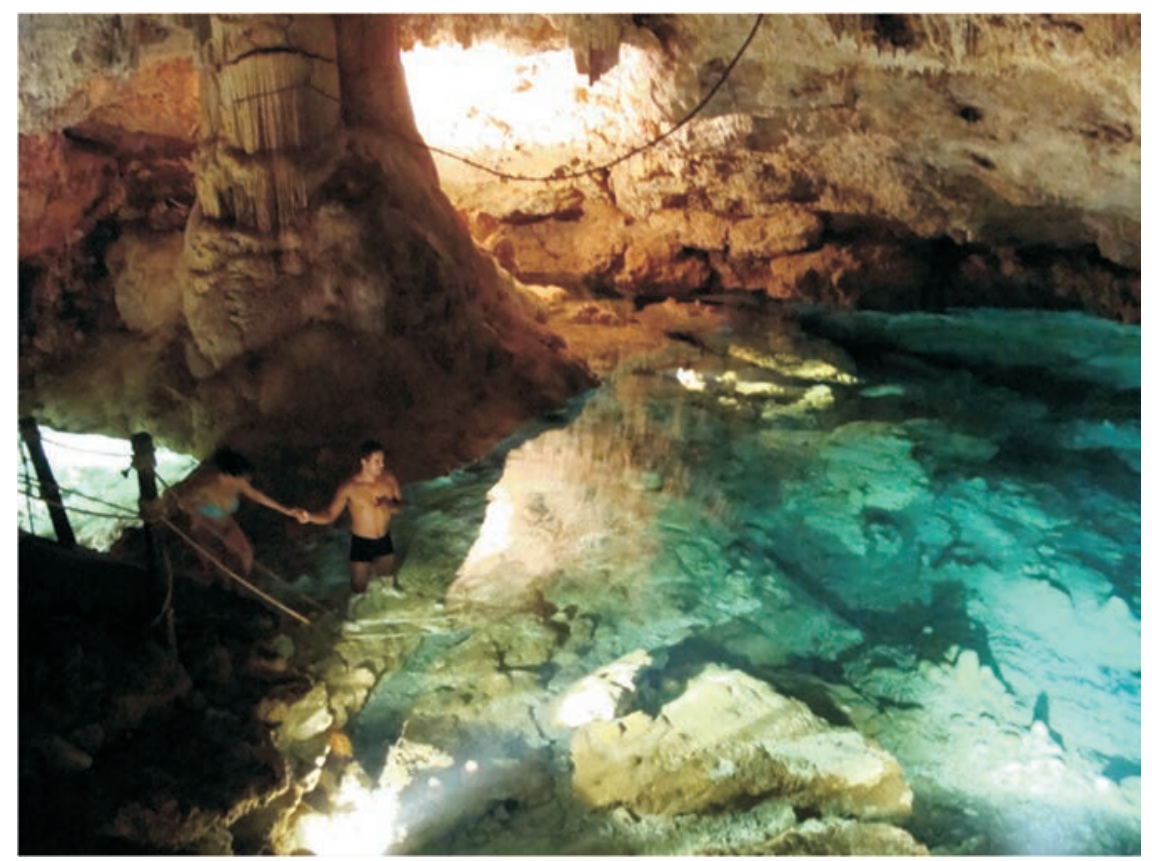

Figura 20. Cenote en la hacienda de Sotuta de Peón

maya funciona, de hecho, sobre la dinámica de la evocación de un pasado fuertemente imaginario que la arqueología se ha esforzado en definir; y la reconfiguración actual de estos espacios se hace proyectando los discursos de los imaginarios construidos a partir de las maneras de evocar.

Toda la narrativa maya comenzó con el encuentro de un experimentado arqueólogo viajero y las ruinas de Copán. John Lloyd Stephens (1841) venía de recorrer el Medio Oriente donde desarrolló la habilidad de escribir espléndidos relatos de viaje, que en nuestros días han sido reconocidos como parte del discurso del descubrimiento y colonización europeos. Una narrativa iniciada por los cronistas españoles del siglo xvı, llevada a un nivel científico por Alejandro de Humboldt, ${ }^{1}$ y que autores como William Dampier ${ }^{2}$ en el siglo xvIII transformaron en informes de inteligencia imperial, desarrollados también al nivel científico del siglo xIX por viajeros como Richard Burton. ${ }^{3} \mathrm{Y}$, al mismo tiempo, esta literatura en su tiempo fue publicada como narrativa literaria romántica como describe Edward Said en Orientalismo. John Stephens vino también con una tarea económica

\footnotetext{
${ }^{1}$ Incluso, en el segundo volumen de Incidentes de Viaje en América Central, Chiapas y Yucatán, cita a sus predecesores como informantes: Bernal Díaz del Castillo, Hernán Cortés y Alejandro von Humboldt. (Stephens, 1969, II: 444-453).

${ }^{2}$ Cf. Dampier, 2004.

${ }^{3}$ Cf. De Otto, 1996.
} 
y política clara: encontrar el camino para abrir el canal interoceánico que establecería una comunicación barata y rápida entre las costas oriental y occidental de Estados Unidos, y que finalmente se realizaría en Panamá. Incluso tenía un nombramiento oficial: era el embajador oficial de Estados Unidos ante la República Centroamericana, aunque llegó cuando ésta se disolvía. Luego construiría y dirigiría el ferrocarril del istmo de Panamá.

Pero su mayor trascendencia fue que encantó al mundo con una retórica literaria expresada en un tono que sólo encontraremos 30 años después cuando Charles Dodgson escribió que "Alicia se encontraba en la actitud de no esperar más que ocurrieran sino cosas fuera de lo normal”. Y más sorprendidos estaríamos si no supiéramos que este tono había sido tomado directamente de las novelas de caballería y de viaje medievales, como la narración anónima del siglo XIII, Demanda del Santo Grial, y el relato del xiv de Jean de Mandeville llamado Libro de las maravillas del mundo.

Así, Stephens escribiría (1969, I: 99):

Cuando llegamos a Copán, fue con la esperanza, más que la expectación, de encontrar maravillas.

Muy semejante es el estado de ánimo con el que la gente de hoy gasta grandes cantidades de dinero y viaja largas distancias para visitar los viejos emplazamientos mayas. Stephens (1969, II: 356) también describió vívidamente la rutina de evocación necesaria para darle significado y disfrutar la visita a una ciudad en ruinas:

Vivimos en el arruinado palacio de sus reyes; subimos a sus desolados templos y caídos altares; y dondequiera que nos movíamos vimos evidencias de su estilo, su habilidad en las artes, su riqueza y poder. En medio de la desolación y ruina miramos al pasado, clareamos la selva, e imaginamos cada edificio en su perfección, con sus terrazas y pirámides, sus ornamentos y esculturas, grandes, elegantes e imponentes, sobreponiéndose al inmenso llano deshabitado; trajimos nuevamente a la vida a la extraña gente que nos observaba tristemente desde las paredes; los vimos, en elaborados trajes y adornados con penachos de plumas; y frecuentemente imaginamos una escena de única y seductora belleza y magnificiencia, encarnando las creaciones de los poetas orientales [...] En la novela de la historia del mundo nada nunca me impresionó más profundamente que el espectáculo de esta alguna vez grandiosa y adorable ciudad (Palenque), transtornada, desolada y perdida; descubierta por accidente, rodeada por millas de bosques y sin un nombre para distinguirla.

La misma emoción persiste en los actuales visitantes como podemos ver en el poema "En Tikal" de William Bronk, ${ }^{4}$ cuyas reflexiones nos ayudan a fijar el objeto de este trabajo. En el tercer párrafo del poema nos encontramos a nosotros

4 “At Tikal”, en Eliot Weinberger, 1992: 238. 
mismos en nuestro presente y, a la vez, en el tiempo del poema, en el futuro. Es el mundo del observador, el tiempo del observador, el visitante en la interacción actual con los elementos que le ayudan a evocar el pasado, el tiempo de los constructores, el tiempo de los habitantes de la ciudad, ese mundo:

Es siempre difícil, así, sin tener un mundo, imaginar uno, ir a un confín distante y apartado e imaginar, poner murallas ya sea dentro o fuera, construir, una especie de jaula por el hecho de sentir los barrotes a nuestro alrededor, dar forma a un mundo. Oh, es siempre un mundo y no el mundo.

Así, los mayas construyeron un mundo, pero no el mundo, como quizás querían, no el cosmos, sino sólo un determinado mundo. Precisamente, David Freidel, Linda Schele y Joy Parker (1993) explican que en la ontología maya existir es advenir de otro nivel de existencia, otro nivel en la ceiba sagrada, sea desde los 9 inframundos de Xibalbá, o de los siete superiores. Niveles que también, al mismo tiempo, en una particular sincronicidad y rotación, eran diferentes momentos del tiempo y diferentes colores relacionados con las cuatro esquinas de su universo, sostenidas por los bacabob correspondientes. Existir, según se canta en la danza dramática guatemalteca del Rabinal Achí, es estar parado entre la tierra y el cielo: el nacimiento, la instalación de un gobierno o coronación de un rey y la erección de una estela, se describían con la misma palabra y glifo. Freidel, Schele y Parker lo traducen como aparecer, tomar forma.

El Pop Vuh (el nombre correcto del Popol Vuh de acuerdo con Adrián Chávez, 1979) dice que al principio los dioses y las cosas tomaron forma. Y esto es producir, producir vida, dicen hoy los campesinos mayas; es intercambiar energía vía el sistema y ceremonia de la ofrenda con los otros niveles del mundo, para que las cosas aparezcan en este nivel.

De tal modo, los constructores tuvieron que originar una forma y verse atrapados por ella. Así que debemos coexistir con estas ciudades, su cultura y su universo. Pero hay maneras de hacerlo y el conflicto radica en cómo hacerlo, de qué manera. Y los elementos de esta lucha se hallan en lo que asumimos o creemos de sus constructores, sus habitantes; en la relación entre los mayas antiguos y los actuales; en la relación de estos con las naciones modernas que incluyen al mundo maya; en la relación con el medio ambiente y, finalmente, en la forma de la producción de la vida diaria, que para los mayas era su mayor interés, el resultado final de su comprensión del universo.

Conocían las montañas, y la selva, el sol, las estrellas parecían estar allí. Pero incluso después de que arrasaran la selva y la quemaran y plantaran el maíz que les daba consuelo, no estaban satisfechos. Querían la forma de las cosas. imaginaron un mundo y fue como si allí estuviera... 
Aquí, en la primera parte del poema, Bronk refleja el universo de los constructores, el deseo, el sueño, la utopía, su necesidad: nuestro pasado remoto.

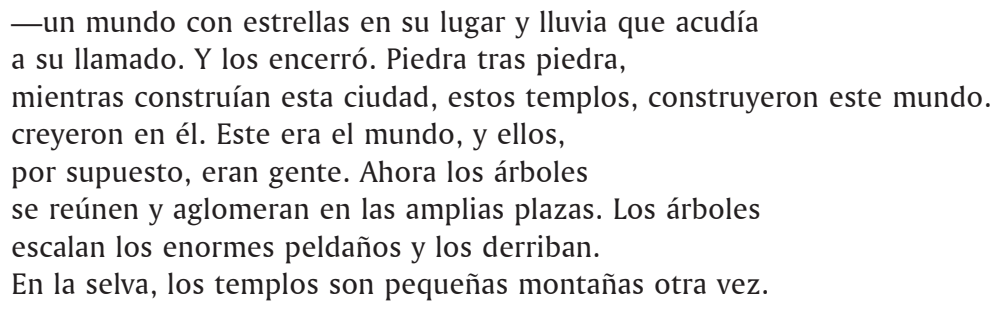

Y en la segunda parte, con la síntesis sólo accesible al entendimiento poético y su expresión, nos remite al mismo tiempo, al tiempo de los habitantes y su transcurso, al destino inexorable de los esfuerzos humanos. Nos describe cómo lo que originalmente era una imitación ritual de montañas, después de la desaparición de los constructores se convertiría en verdaderas montañas hasta que la arqueología las devolvió a su estado de edificios sagrados y seculares.

Esta sección se mueve históricamente desde el tiempo de los habitantes de la ciudad al tiempo del descubrimiento por nuestra sociedad como parte del misterio de la selva. Justo como la descripción de Copán de Stephens, que inició toda la narrativa "maya": la magia y el misterio; su admirable habilidad intelectual materializada en las piedras y una sensación de súbita desaparición que los fundió con la selva de tal manera que parecía imposible relacionarlos con los indígenas contemporáneos. El truco retórico capaz de reinventar a los constructores mayas de las antiguas ciudades como seres excepcionales es simple. Bastó mencionar la invasión de la selva para hacer pensar que habían dejado las ciudades en una apresurada huída. Los mayas no pudieron ser presentados desde entonces sólo como una civilización antigua, sino deben presentarse como un misterio. En este año, el Instituto Nacional de Antropología e Historia produjo una serie sobre los mayas en el History Channel, y tuvo que llamarla El misterio maya, aunque su contenido fuera justamente demostrar que no existe tal misterio.

Aquí otra vez podemos regresar a un poema de William Bronk. En "Los no leídos glifos mayas" (Weinberger, 1992: 240), nos encara con el problema de la comunicación:

Eran distintos a nosotros en muchos sentidos. Pero sabemos algo acerca de ellos, bastante, de hecho.

Eran hombres, lo que me hace pensar si tuvieron algo más que decirnos, que lo que tenemos que decirnos, nosotros, unos a otros, o más aún, si tuvieron una mejor manera de decirlo, de darse a entender. Me parece que todos hablamos con glifos indescifrados tanto como ellos. Muy bien. Me gustaría saber ¿qué novedad tienen? No, Trataría de hablar 
con quien fuera si creyera que pudiera. Tú.

Me gustaría hablarte. ¿Qué es lo que sabes?

Y, nuevamente aquí, remite la cuestión de la comunicación a un problema actual, a un problema nuestro. Pone a los mayas en el limbo de lo inaccesible; sin embargo, hay novedades. Ahora podemos leer los glifos mayas, y en parte porque Linda Schele pensó que los mayas contemporáneos podrían todavía leerlos. Para leer los de Palenque, Linda pidió ayuda en el ejido adyacente a la zona arqueológica para comprobar su suposición de que estaban escritos fonéticamente en ch'ol o protochol, y así fue. ${ }^{5}$ Así, los mayas jamás han estado en el limbo. Vencidos, diezmados, reducidos a la esclavitud, forzados a migrar como ahora, sí. Pero están tan vivos hoy que son una importante fuerza política en Guatemala, y en 1994 protagonizaron una rebelión bastante posmoderna con impactos simbólicos globales.

Y, en efecto, la gente maya no perdió su conocimiento cosmológico, aunque los nuevos procesos de reorganización económica regional y macrorregional, y el nuevo papel de la cultura en la economía están forzando una transformación dramática y posiblemente irreversible.

En este proceso actual, a pesar de la profundidad y complejidad de la relación de contacto que significa la visita a una antigua ciudad maya, esto no parece ser suficiente para los promotores turísticos. Después de una larga lucha, ahora parece natural que Chichén Itzá sea usado como un escenario para conciertos. Y si bien el primero fue dado por el finado Jorge Reyes, que con un profundo conocimiento de la música prehispánica y usando instrumentos indígenas hacía una fusión etnomusical, y se presentaba gratis, luego el monopolio privado telefónico cobró por presentar a Luciano Pavarotti como inicio de una lista de cantantes modernos.

Luego entonces, las antiguas ciudades ya no pueden ser sólo sitios arqueológicos: tienen que ser locaciones, escenarios y, por supuesto, parques temáticos al estilo de los ornamentos, como explica Iñaki Esteban (2007) el uso de espacios, edificios e infraestructura como detonantes o núcleos de nuevas actividades y procesos económicos. Al mismo tiempo (de alguna manera para poder servir como tales) también se convierten en espacios de comunicación e interacción no significados y donde puede proyectarse cualquier cosa. De tal manera, podrían también remitirnos a la idea de Mark Augé (1993) de no lugares como espacios no significados, a través de lo que de hecho constituye la apropiación virtual y privatización real de los sitios arqueológicos y los paisajes.

Manejando de Cancún a Chichén Itzá por la supercarretera, en la caseta de cobro uno se encuentra con un letrero que lo dirige a una caseta informativa sobre la zona arqueológica. En ella hay un gran letrero de algo llamado el Parque Chichén Itzá y Mayaland, donde se muestra un mapa donde la zona arqueológica

\footnotetext{
${ }^{5}$ Comunicación personal durante el Tercer Congreso Internacional de Mayistas, Chetumal, 1995.
} 
aparece entre ambas cosas, que resultan ser dos hoteles, dando la impresión de que para acceder a la zona arqueológica es necesario pasar por uno u otro. Uno está en la entrada del pueblo de Pisté, y en el otro hasta hace dos años por las noches se organizaban visitas ilegales a la zona (figuras 21 y 22).

Quizás este sea el caso más evidente de apropiación virtual, pero por supuesto no es el único. Los casos más formales están protegidos bajo la forma legal de "concesión". Por ejemplo, en Tulum durante la noche hay que pagarle a una compañía privada para entrar al espectáculo de luz y sonido rentando unos audífonos con grabaciones descriptivas.

Otro truco utilizado cada vez más en las zonas arqueológicas es la construcción de puertas monumentales y centros comerciales a la entrada. En algunos casos, como en Tulum, esto obliga a hacer una caminata de 2 kilómetros o pagar un boleto de un mototren. En el caso de Calakmul la entrada queda a 20 kilómetros de la ciudad, por lo cual se vuelve obligatorio el pagar un boleto de tren a una compañía privada para llegar a ella (figura 23).

Pero el peor caso de estas concesiones de recursos naturales son las playas y arrecifes de El Garrafón y la caleta de Xel-ha a la misma compañía dueña de Xcaret. En el primer caso la compañía sólo agregó infraestructura para practicar algunos deportes y la típica tirolesa que identifica al ecoturismo de aventura para cobrar 50 dólares de entrada. Y en Xel-ha volaron con explosivos la más

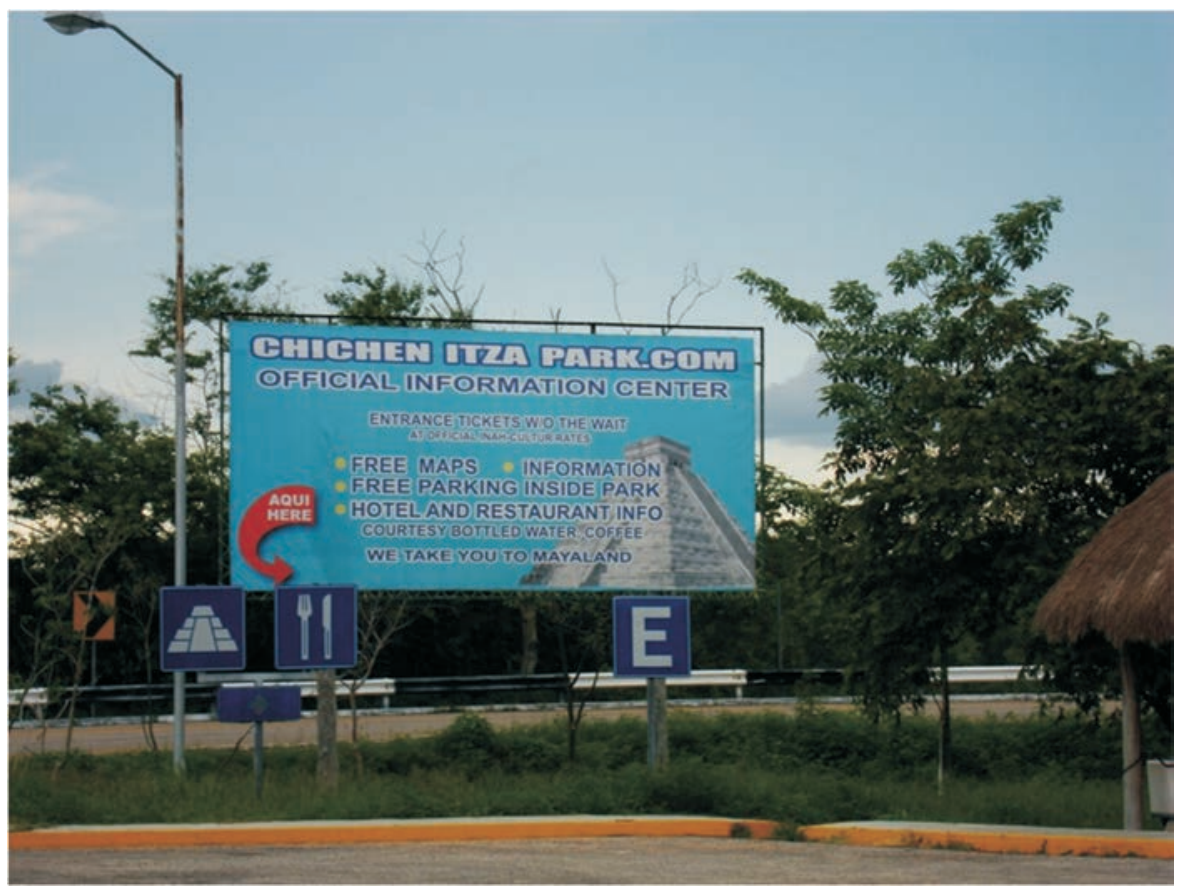

FigurA 21. Anuncio de servicios turísticos 


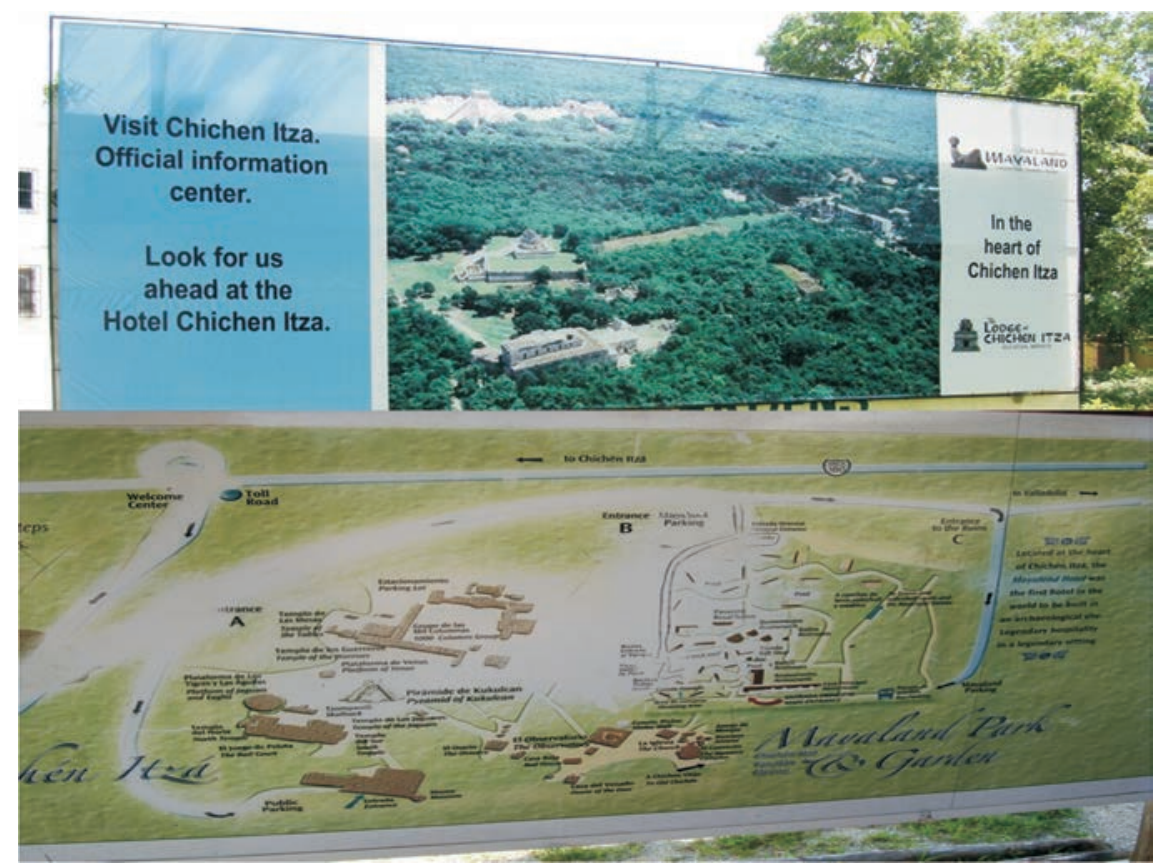

Figura 22. Mapa de la zona arqueológica de Chichén Itzá donde se muestra un par de hoteles

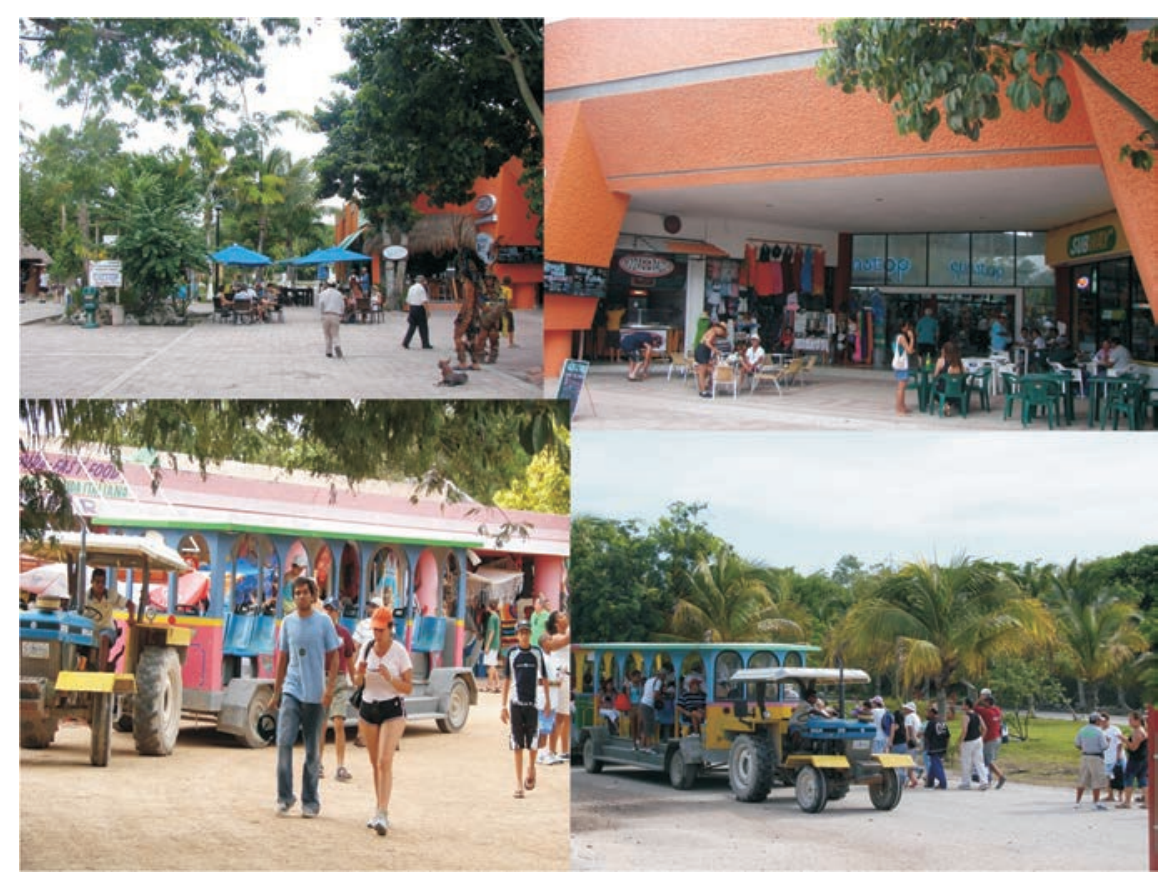

FigURA 23. Entrada a Calakmul 
hermosa de todas las caletas y sus cuevas naturales porque originalmente era muy pequeña para la explotación comercial; construyeron un canal con el mismo método; cerraron y controlaron la circulación de agua; e instalaron una piscina artificial para dar un espectáculo con delfines, reduciendo un espacio natural a un trayecto de actividades de parque que incluye un campamento en la playa para salvar tortugas y la inefable vereda ecológica entre restos muy pobres de vegetación. En estos dos últimos lugares hay una profusión de letreros sobre educación ecológica, quizás porque la legislación mexicana acepta tal educación como paliativa de la destrucción ambiental (figura 24).

No siendo esto suficiente recibieron también la más oriental punta del país, el extremo sur de Isla Mujeres en concesión. Para tener derecho a cobrar por el acceso agregaron una casas tipo inglés y situaron una estatuas sobre el farallón. El problema es que no se trata meramente de lugares aislados, sino de un sistema que tiene como centro a Xcaret (figura 25).

\section{El sistema turístico fractal}

La leyenda urbana de Xcaret dice que "El Pelón" Gonzalo Infante, un productor cinematográfico que produjo y dirigió los videos oficiales de todas las zonas arqueológicas mexicanas para el Instituto Nacional de Antropología e Historia,

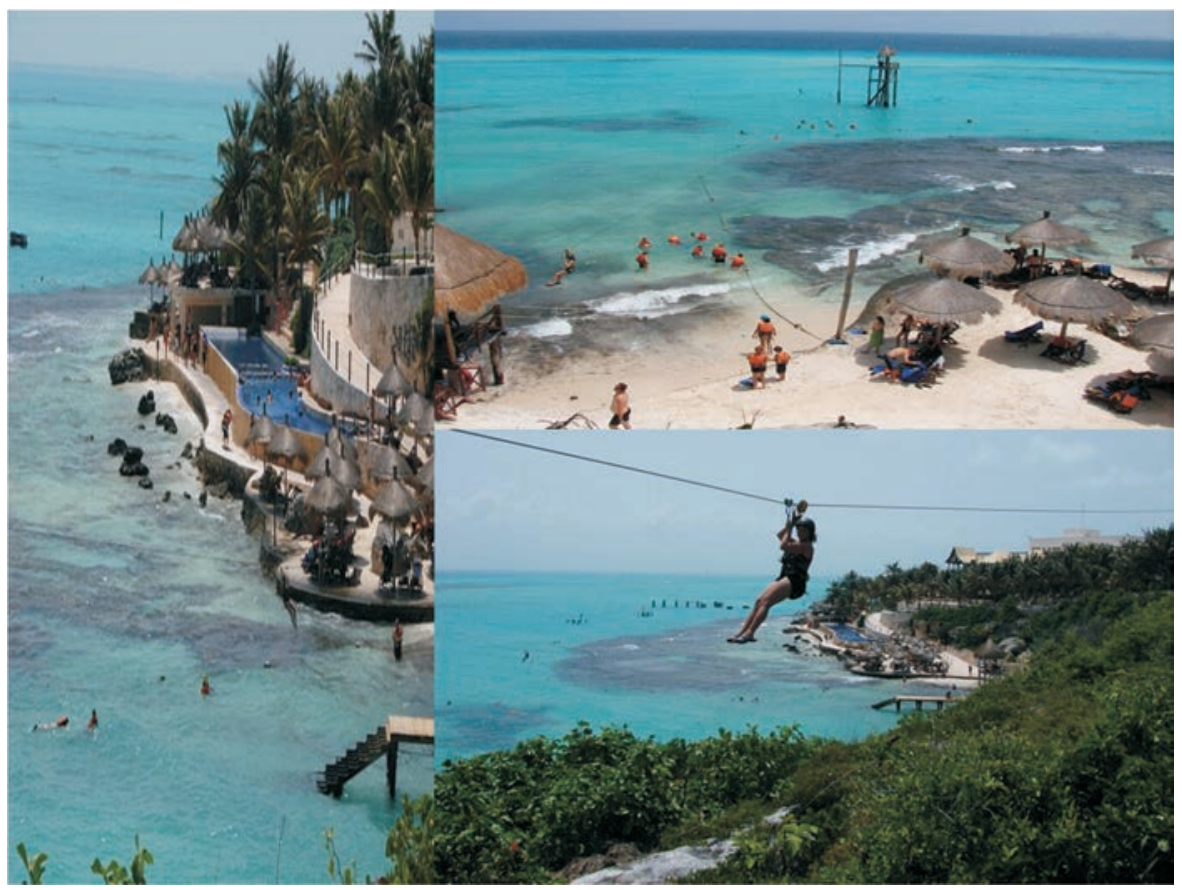

Figura 24. Imágenes de Xel-ha 


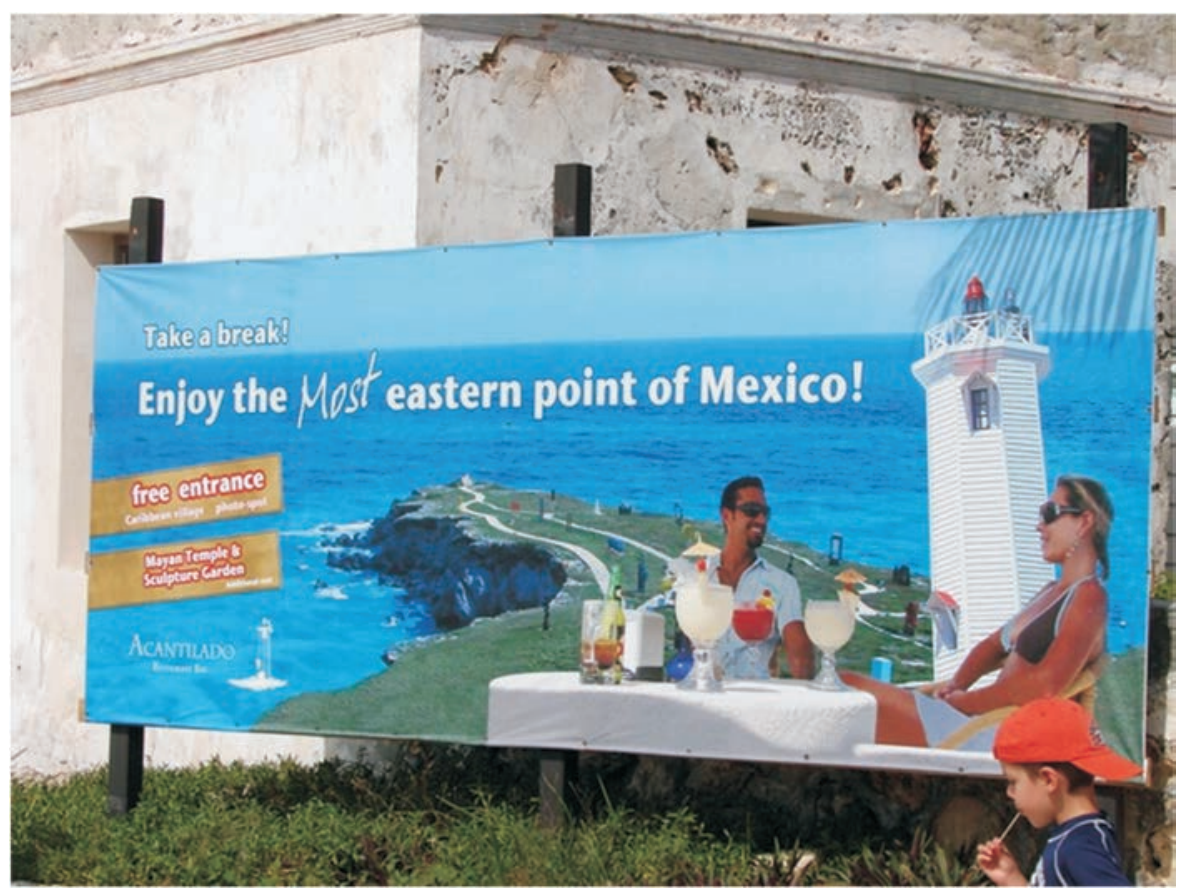

Figura 25. Anuncio de Isla Mujeres

se asoció con la compañía que construía el parque temático maya. Se dice que por eso el diseño de Xcaret y su funcionamiento estuvo planeado y basado en las técnicas de la industria cinematográfica. ${ }^{6}$ Pero la realidad es que el arquitecto Miguel Quintana Pali, comprador original del terreno y principal accionista del proyecto, hizo su fortuna con tiendas de objetos de diseño.

Xcaret fue diseñado para reproducir todas las experiencias y todos los elementos presentes en el mundo maya en un sólo espacio. El lugar original incluía una caleta natural con pirámides y un cenote. Xcaret fue Polé, uno de los más importantes puertos mayas de lo que antes se llamaba la Costa Oriental. Lo que hicieron fue cerrar la caleta y llenarla con peces tropicales y grandes tortugas adultas traídas del mar. También construyeron un acuario, donde tras extraer coral y más animales marinos reprodujeron vistas marinas que amenizan con música new age compuesta especialmente para el lugar y que puede uno comprar en un CD. Construyeron una supuesta villa de pescadores mayas en una de los huecos naturales, un supuesto campamento chiclero, un juego de pelota con sus respectivas gradas y dinamitaron dos túneles para crear un río natural donde hombres disfrazados de peones de hacienda conducen pacíficas lanchas, o donde uno puede rentar equipo para snorkelear bajo tierra como si se encontrara uno

${ }^{6}$ Versión escuchada en reunión de productores cinematográficos. 


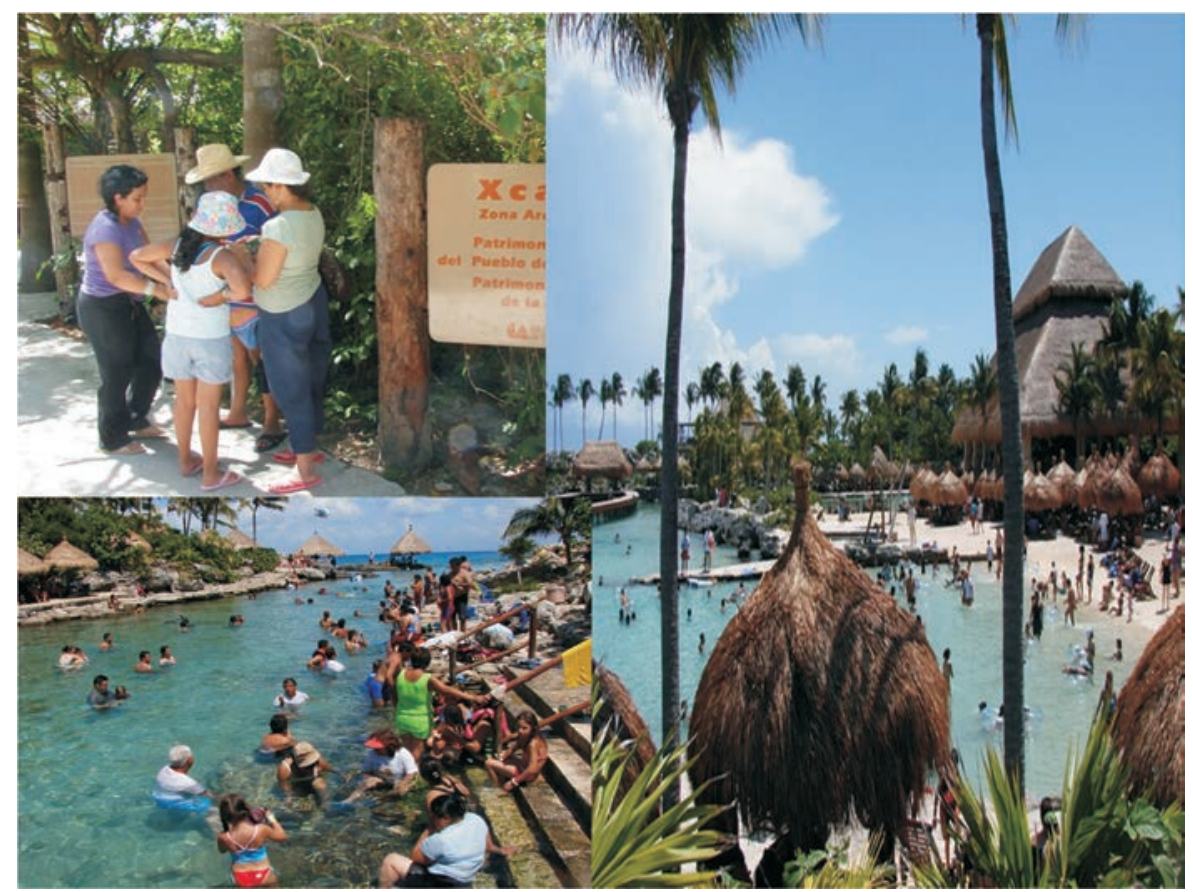

FIGURA 26

en un cenote. Entre otras cosas más, erigieron una colina disfrazada de supuesto panteón mexicano donde se puede celebrar el día de muertos del 2 de noviembre todo el año (figura 26).

El lugar se hizo famoso a nivel nacional e internacional sobre todo por el paseo por el río subterráneo y el realismo del espectáculo de las danzas prehispánicas, que luego se extendió a una representación de toda la historia mexicana como una apología de la civilización impuesta por Europa en una interpretación muy similar a la versión dada por Mel Gibson en su película Apocalypto. En pocos años el lugar capturó la imaginación de las clases medias urbanas del país, convirtiéndose en un destino tan importante como Cancún a pesar de su precio de 50 dólares por día. La publicidad en las calles del Distrito Federal pasó a ser: "La próxima vez que vaya a Xcaret no olvide visitar Cancún” (figura 27).

Sin embargo, lo importante es que Xcaret ahora no es sólo un parque sino un sistema, y en cuanto a su "mensaje" el sitio resulta contradictorio. Supuestamente promueve la conservación natural y la difusión cultural, pero sus actos son y producen los efectos contrarios. Está construido destruyendo un paisaje natural (cierre de la caleta, uso extensivo de la dinamita, túneles artificiales). Al sacar animales de su entorno natural para exhibirlos impide su reproducción en su entorno natural. No hay manera de justificar la extracción de coral; aplasta y 


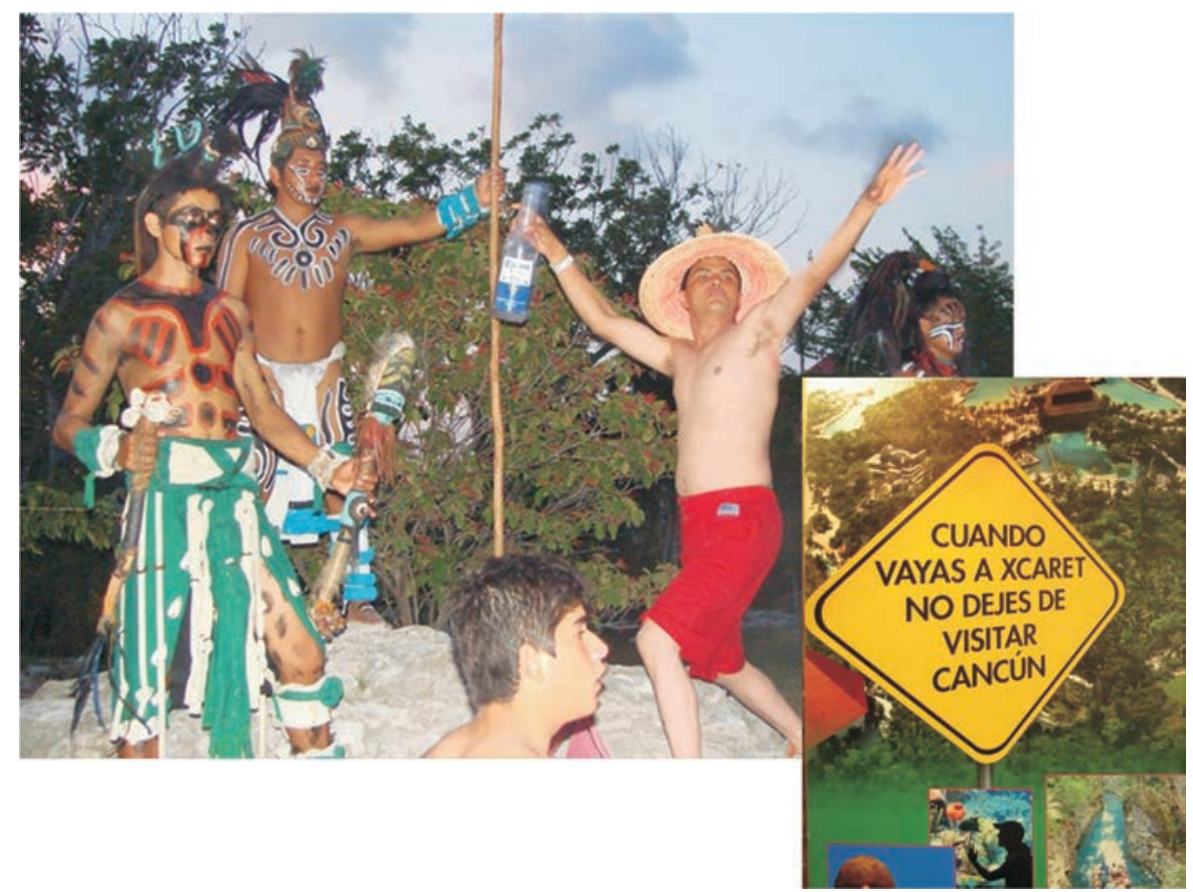

FIGURA 27. Imagen y anuncio de Xcaret

banaliza un verdadero sitio arqueológico usando a las pirámides como mero soporte para que la gente se tome fotos con personajes espectacularmente disfrazados de sacerdotes y guerreros mayas; y distorsiona actividades como presentar el juego de pelota de fuego purepecha como maya (porque es más espectacular), y narrar una versión bastante sesgada —incluso racista — de la historia mexicana en su espectáculo nocturno (figura 28).

Cancún comenzó, como todo mundo se enteró luego de que el huracán Wilma lo desnudó de su arena, como una playa artificial creada por el totalmente antiecológico proceso de extraer arena del fondo marino, lo que obliga ahora a reconstruir las playas aquí y en Playa del Carmen cada año. De manera análoga, Xcaret es el ejemplo del éxito económico de las simulaciones en el sentido descrito por Jean Baudrillard (1998). Pero al mismo tiempo Xcaret evidenció un proceso progresivo pero callado de migración de turistas que buscaban lugares naturales ante la urbanización y miamización de Cancún. El nuevo sitio de interés de este tipo fue Playa del Carmen, que al crecer en parte por su cercanía con Xcaret (además por su natural posición privilegiada frente a Cozumel), comenzó a cambiar hasta convertirse en un lugar focal de una cultura de alto consumo y exhibición, sobre todo para el sureste del país. Al grado de que la revista de sociales más importante de la región tiene el nombre de su calle y mall abierto emblemática: La Quinta. Esto llevó a este turismo a seguir avanzando hacia el 


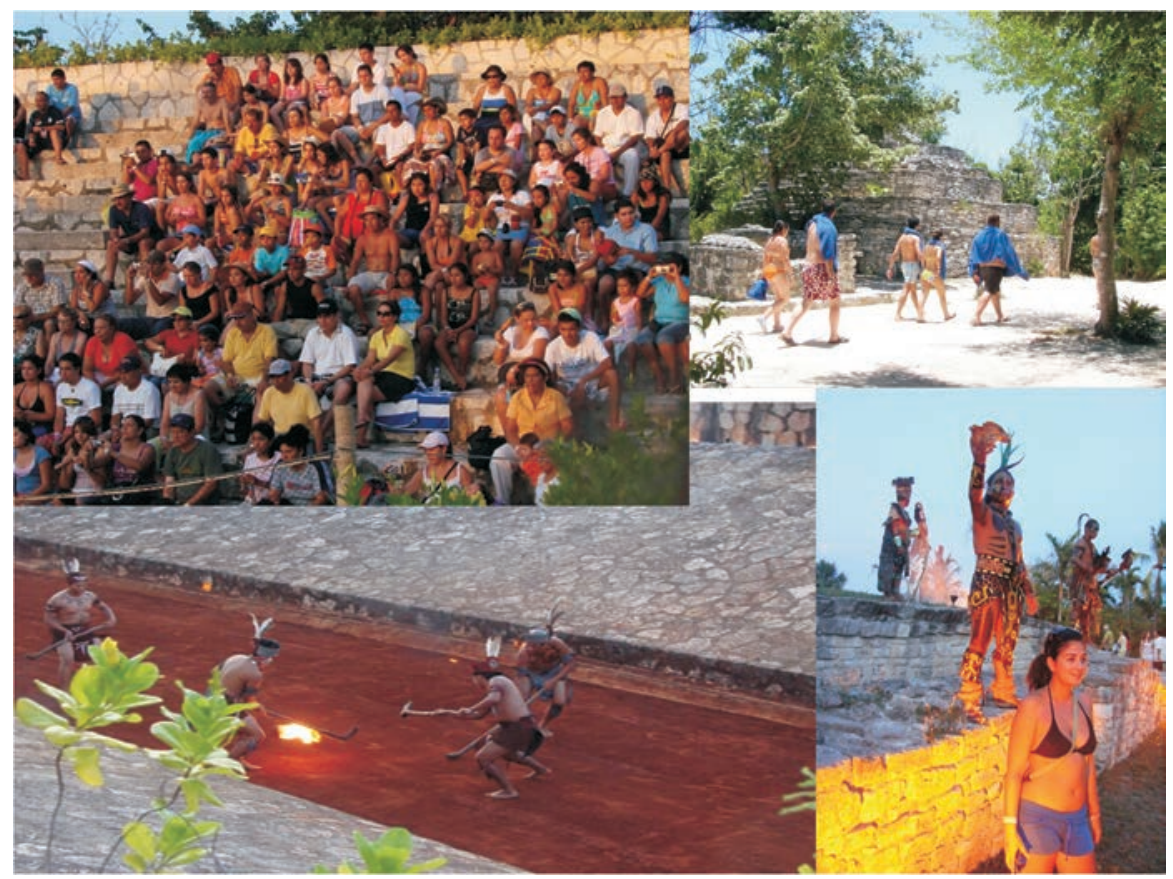

Figura 28. Espectáculos en Xcaret

sur, hacia Tulum, y ya en los 90 a Majahual, cuando no hasta el cayo Amber Gris o lugares más accesibles de Belice. Esta progresiva mudanza y la capitalización que le siguió convencieron al gobierno de la necesidad de regionalizar y organizar la oferta estableciendo como espacios separados Cancún y la Riviera Maya, e iniciando en torno a Majahual y el sur del estado la llamada Costa Maya. Para mediados de la primera década del siglo, se llegó a la conclusión de que Tulum podía independizarse, se le dio nivel de municipio y se inició la construcción de un aeropuerto internacional.

Finalmente, como resultado de este proceso, tenemos ahora en el estado de Quintana Roo un mapa turístico fractalmente organizado, donde las estructuras se repiten y recrean a distintas escalas, y cuyo sentido está relacionado con la idea de microcosmo virtual de Xcaret. Los sistemas son fácilmente identificables en los grandes trazos programáticos del gobierno dividiendo la zona de Cancún, la Riviera Maya y la Costa Maya con el emergente Tulum separándose de la Riviera; pero al mismo tiempo, la estructura se repite en lugares más pequeños que contienen los mismos elementos como son las dos islas, Cozumel e Isla Mujeres. Además lo podemos encontrar, incluso reproduciendo ya no sólo el Mundo Maya, sino supuestamente todo el país mediante simulacros en cada uno de los hoteles todo incluido. Aquí es frecuente que los bloques de cuartos, de bungalows o los restaurantes reproduzcan o se refieran a distintas regiones del país. 
Los elementos constantes del sistema son:

- Una zona terrestre de conservación de la naturaleza.

- Una zona de conservación de arrecifes.

- Un parque temático.

- Un delfinario.

- Una zona arqueológica importante.

- Una zona de hoteles de Gran Turismo donde cada hotel tiende a reproducir en sí mismo el sistema.

- Un desarrollo inmobiliario de clase alta.

- Un sistema de cenotes.

- Un vecindario o ciudad especial para los trabajadores de servicios turísticos.

- Una zona turística con precios y servicios para clase media, relacionada normalmente con los pocos espacios públicos restantes.

- Uno o varios malls centrales.

- Pequeñas zonas marginales de turismo ejidal, tradicional mexicano o hippie con sus respectivos cenotes, playas y hoteles.

Aunque el sistema está materializado sobre el territorio del estado de Quintana Roo es, a su vez, parte del sistema mayor de El Mundo Maya. Por ello considera como elementos adyacentes las reformulaciones de Mérida y Campeche con base en las propias narrativas de origen histórico y sus propios sistemas, pero sobre todo resulta interesante cómo tiene efectos fuera de su propia zona. Primero tuvieron un fuerte efecto disgregador sobre todos los pueblos del centro de la península por la gran oferta de trabajo que significaron el auge de crecimiento tanto de Cancún como de la Riviera Maya, que vino a paliar y equilibrar el proceso de destrucción de la agricultura que significó la integración al Tratado de Libre Comercio y el cambio de políticas agrarias. Luego vino el auge entre 1990 y el 2003 de las maquiladoras en torno a la ciudad de Mérida con el mismo efecto. Finalmente uno puede ver ahora el centro del estado con las tierras abandonadas sin producir ya ni henequén ni maíz, y sin el paliativo de los anteriores procesos de oferta de plazas laborales de escasa capacitación. Frente a esto los gobiernos locales y federal están impulsando proyectos de turismo local, pero que siguen el modelo de turismo de experiencia, modular y fractal de Xcaret, como condición para ser apoyados. De hecho, al norte de Chichén Itzá el gobierno de Yucatán comenzó a construir un gran proyecto llamado Casa de la Cultura Maya para inventar un nuevo centro de atracción turística, donde dice que albergará todo el conocimiento y las expresiones de esta civilización (figura 29). 


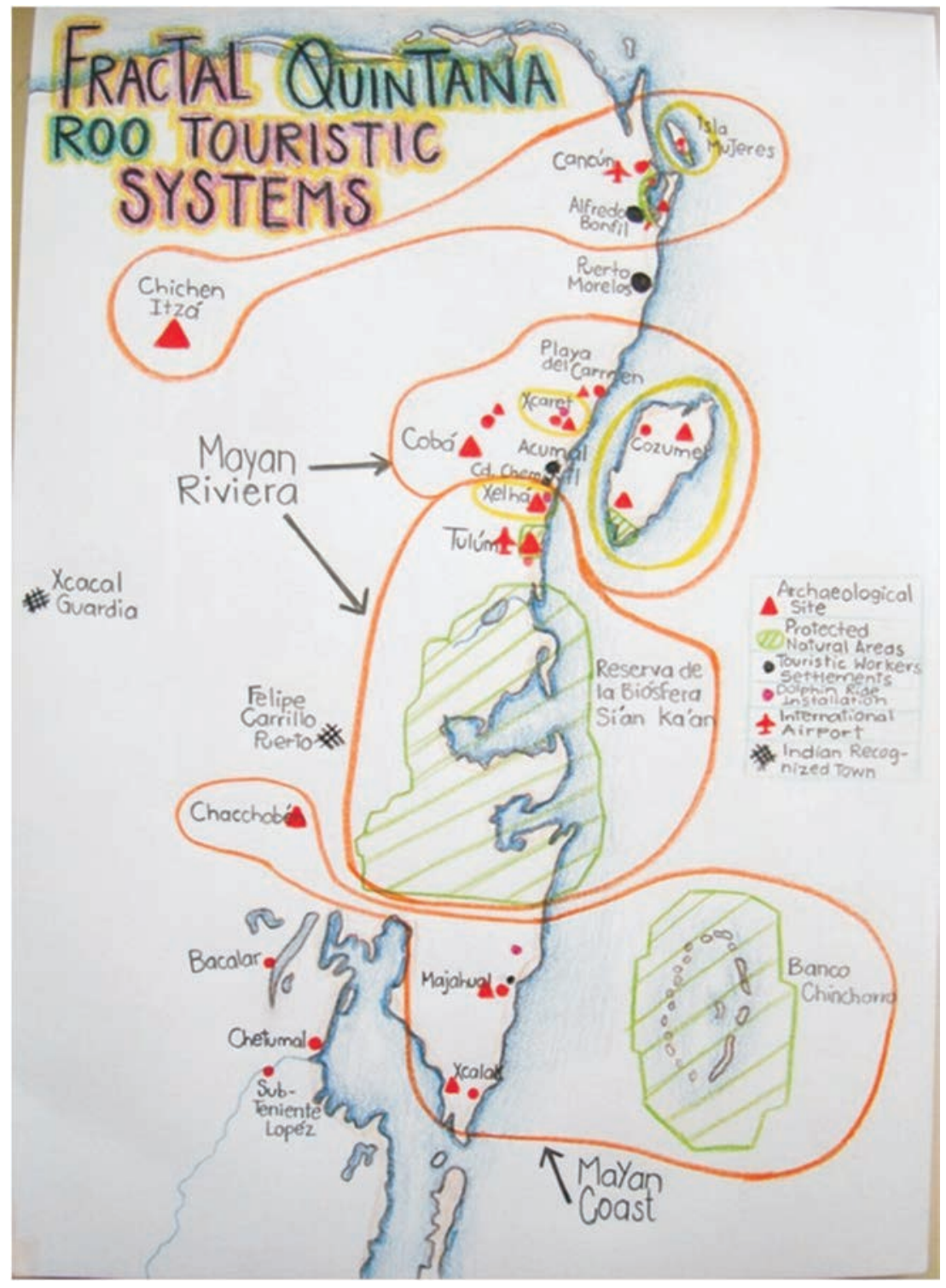

FIGURa 29. Proyectos turísticos en Quintana Roo

\section{Conclusiones}

Lo que es importante no es sólo que un turista ocasional pueda dejar el área con una experiencia reducida, artificial y controlada en un hotel todo incluido; sino que toda el área del estado de Quintana Roo ha sido transformada, rediseñada, 
para hacer accesibles lo que mayormente es una mera simulación de las posibles narrativas mayas; y que la evidente simulación, el parque temático de Xcaret, ha venido, para decirlo en términos de la teoría del caos, a convertirse en el principal atractor de orden de este universo transformado y diseñado. Ahora el parque es la estructura que informa y da sentido a los nuevos planes para todo tipo de nuevo desarrollo de proyectos materiales, construcciones y transformaciones de ecosistemas. Incluso para la recuperación o reconstrucción de los elementos antiguos (figura 30).

Xcaret, a su vez, no es sino una representación tridimensional de las narrativas de lo que realmente fue la vida real material en el área en diferentes tiempos. La transición a la economía inmaterial en la península de Yucatán ha significado el cambio de las viejas actividades productivas a un turismo basado en su evocación. Y, a su vez, esta transición se explica por la inclusión de esta área como parte de dos macrorregiones: la Mesoamérica de la programación de los organismos internacionales, y la Norteamérica del Tratado de Libre Comercio, donde se decidió que la producción de alimentos, particularmente del maíz, se realice en los grandes llanos del centro de Estados Unidos y Canadá.

Así, los rituales mayas religiosos y de curación y las actividades de producción de vida material desde el sistema de milpa para la producción de maíz y la construcción de pirámides, lo mismo que la explotación forestal para extraer el palo de tinte por los bucaneros y piratas ingleses, la de maderas finas, la extracción de chicle y la explotación del henequén por las grandes haciendas, se han convertido en meros relatos que sostienen ahora la nueva actividad económica prioritaria. Esta última sólo tiene sentido y viabilidad en función de una integración a un macroespacio económico mayor (mercado) al que le ofrece la función de reposo y diversión. Los límites de este espacio implican una tercera macrorregión que no sólo incluye el oriente de Estados Unidos, sino también Europa y depende totalmente de la comunicación aérea.

Es un proceso de virtualización en tanto virtualizar significa, fundamentalmente, reducir algo a sus elementos básicos, que son esencialmente transportables, transmisibles, generalizables y consumibles. Reducir todo a una mera información. De manera que la reformulación de los centros urbanos de Mérida y Campeche, los lugares culturales significativos como las zonas arqueológicas, lo mismo que los escenarios y espacios rurales, y aún los paisajes naturales han sido reformulados para exaltar este tipo de información o contenido por sobre la "natural" acumulación y confluencia de procesos y formas de vida históricos que normalmente le daban una apariencia palimpséstica a los lugares públicos. Incluso, recientemente, el actual gobierno federal convirtió esta reducción y "normalización" de los lugares turísticos en política pública bajo el programa de Pueblos Mágicos, donde el objetivo central y casi único es estabilizar y homogeneizar una "imagen urbana".

En este proceso, la valoración actual no es intrínseca al objeto o hecho presente, sino en tanto permite representar una narrativa que sirve de soporte a 


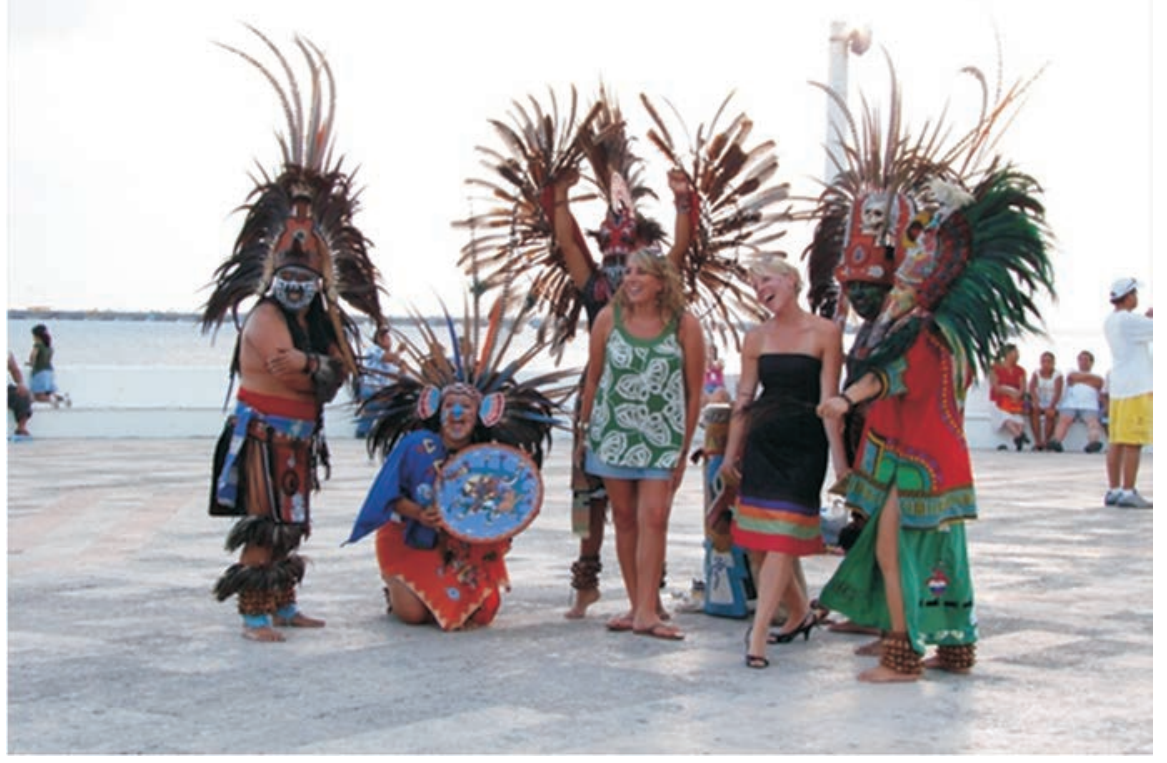

FIGURA 30. Turistas acompañadas por personajes con trajes autóctonos

una actividad rentable. En este sentido un hotel de diseño minimalista, un hotel boutique, tiene el mismo valor que una pirámide; y al mismo tiempo se justifica destruir o cortar una pirámide, si esta no es tan icónica como el Castillo de Chichén Itzá. Esto le ocurrió a varios templos de Xel-ha que tuvieron que competir contra la ampliación de la carretera de la Rivera Maya.

Lo importante es que estamos en un proceso de racionalización del espacio y el territorio en general, de la ecología, de los paisajes y sus usos sociales, y de la cultura, cuya sustentabilidad en el corto plazo es cuestionable.

Todavía podemos ver hoy a la península y los usos turísticos de los diversos paisajes bajo la forma natural de todo paisaje: un palimpsesto de usos y prácticas diversas que refieren a diversos grupos sociales y diferentes tiempos. Pero junto con una progresiva apropiación privada de los recursos naturales y culturales, algunas veces sólo virtual pero rentable, se da una progresiva homogeneización.

Esto por un lado tiende a hacer que la vida actual sólo sea posible en un sentido económico que descansa en formas de vida ya inexistentes, periclitadas, en un sistema cada vez más excluyente, no sólo por la concentración territorial que implica, la limitación del acceso a los lugares ecológicamente relevantes como playas, cenotes, etc., sino también por su limitada necesidad de fuerza laboral y la exclusión de cada vez más amplios sectores sociales del disfrute turístico de los recursos. 
Resumiendo, el viejo turismo se hacía para experimental paisajes y formas de vida de la gente local actuales, reforzando identidades y creencias o incluso ideologías actuales, vivas; pero ahora se impone una experiencia prefabricada por un acto de recuperación de un imaginario sobre lo que debió haber sido la vida de la gente local antes, mientras la cultura local actual está siendo destruida o al menos obstaculizada por la construcción de escenografías donde tales imaginarios son proyectados. Al mismo tiempo, por supuesto, la vida actual local pierde toda centralidad como objetivo vital y sólo existen dichas representaciones de imaginarios en función de la gente de lugares lejanos que viene a hacer turismo.

La gente local actual, particularmente la indígena, los mayas contemporáneos, han sido reducidos a una nueva cultura de meseros, taxistas y camaristas, con muy poco espacio vital para mantener una cultura, lenguaje y tradición de resistencia como lo hicieron a lo largo de los cinco siglos pasados. Más aún, esta integración a un solo espacio económico también está significando la desaparición de la cultura campesina. Ante la imposibilidad de la industria turística y de la maquiladora en torno a Mérida de absorber a la mayor parte de la población, ésta intenta migrar a los Estados Unidos. Lo que, paradójicamente, libera más territorios para, bajo la apropiación corporativa, seguir impulsando la ficción de un espacio primordialmente natural por despoblado.

Podemos decir que el territorio de la península maya y su paisaje ha sido reformulado por un amplio sistema y diversos subsistemas, que en el caso de Quintana Roo tiene abiertamente un carácter fractal incluso en sus subsistemas meramente empresariales (el subsistema de parques de la empresa de Xcaret), y que al mismo tiempo tiene como sentido organizador el modelo de simulación del propio Xcaret.

Pero al mismo tiempo podemos pensar que se sostiene en general por dos modelos que también funcionan a nivel de arquetipos:

- Miami como imagen urbana y fuente de estética y aspiración social.

- Xcaret como modelo de experiencia posible o accesible.

Y tiene varias narrativas como base o referencia, de las cuales aquí expusimos ejemplos de:

- El misterio y sabiduría de los mayas antiguos.

- El brillante pasado de las haciendas henequeneras.

- Lugar de encuentro con la naturaleza primordial.

- La conservación del medio ambiente.

Encontramos que ahora el territorio de los rebeldes mayas del siglo xIx, los Cruzob, está determinado por una proyección de organización turística corporativa del espacio basado en las características originales del paisaje, los ecosistemas y el pasado cultural. Pero han sido forzados a un formato accesible 
en todo sentido al turista, de manera inmediata y en todo emplazamiento de manera total pero básicamente virtual, como una experiencia segura, controlada, superficial y artificial, que aunque dice promover la conservación natural y la difusión cultural en realidad como proceso material y subjetivo destruye ambos patrimonios. Se trata además de un proceso dependiente de la integración de la región a un espacio económico integral más amplio, donde el rol asignado es el del desarrollo de la economía inmaterial como único medio para obtener incluso alimentos, en una situación de amplísima vulnerabilidad por la absoluta dependencia de un grueso y permanente flujo de turistas de zonas lejanas que llegan por vía aérea.

Uno de los resultados inmediatos más graves es la jerarquización de zonas y áreas en una ya evidente segregación social espacial que era desconocida en la zona y en el país en tiempos anteriores. Al mismo tiempo las características ambientales y culturales que eran dominantes todavía a principios de los años 70 , se han convertido en hechos escasos y reducidos generando una situación esquizofrénica donde, si la atracción principal de la región eran sus condiciones abiertas exteriores, ahora turistas y población local se vuelcan al disfrute tanto de los bienes naturales como de los culturales en espacios reducidos en un minimalismo vital antes desconocido en la región.

En el inició del Corazón de las tinieblas (Heart of Darkness), Joseph Conrad hacía referencia a una particular dinámica en la que lo que había sido el lugar de lo misterioso y desconocido como la antigua Bretaña para los romanos, ya en el siglo xIx era justamente, teniendo como sede a la gran ciudad del Támesis, Londres, lo contrario. En este caso, los lugares del misterio, los santuarios de lo desconocido que habían sido abandonados por los pueblos antiguos y ocultados y destruidos por la nueva civilización europea y mestiza local, se convierten en simulacros reformulados y controlados. Y no están rodeados de naturaleza incontrolada y pueblos tradicionales de cultura intacta sino de selvas, petenes, praderas y pantanos destruidos, campos agrícolas abandonados y pueblos empobrecidos en plena diáspora.

\section{BIBLIOGRAFÍA}

Anónimo

1982 Demanda del Santo Grial, edición preparada por Carlos Alvar. Madrid: Editora Nacional.

Augé, Marc

1993 Los No Lugares. Antropologías de la Sobremodernidad. Barcelona: Gedisa.

Bajtín, Mihail

1989 Teoría y estética de la novela. Madrid: Taurus. 
Baudrillard, Jean

1998 El paroxista indiferente. Barcelona: Anagrama.

2000 Pantalla total. Barcelona: Anagrama.

Chávez, Adrián

1979 Pop Wuj. México: Instituto Nacional de Antropología e Historia, Ediciones de la Casa Chata.

Conrad, Joseph

1980 Heart of Darkness. Londres: Penguin.

Dampier, William

2004 Dos Viajes a Campeche. México: Porrúa.

De Otto, Alejandro

1996 El viaje de la escritura, Richard Burton y el este de África. México: El Colegio de México.

Eliade, Mircea

$1998 \quad$ Lo sagrado y lo profano. Buenos Aires: Paidós.

Esteban, Iñaki

2007 El efecto Guggenheim. Barcelona: Anagrama.

Freidel, David; Linda Schele y Joyce Parker

1993 Maya Cosmos. Three Thousand Years on the Shaman's Path. Nueva York: William Morrow and Company.

Giddens, Anthony

$1991 \quad$ Modernity and Self Identity. Stanford: Stanford University Press.

Goethe, Johannes Wolfang

1991 Obras Completas. Tomo IV. Madrid: Aguilar.

Greene, Graham

1982 Lawless Roads. Londres: Penguin.

Jodelet, Denisse

1993 "Las representaciones sociales", Psicología social, tomo II; Sergio Moscovici (compilador). Buenos Aires: Paidós, 469-494.

Lawrence, D.H.

1981 The Plumed Serpent. Londres: Penguin.

Lowry, Malcolm

1984 Bajo el volcán. México: Era. 
Mandeville, Jehan de

2002 El libro de las maravillas del mundo. Madrid: Siruela.

Newton, Arthur

1933 The European Nations in the West Indies 1493-1688. London: A\&C Black Ltd.

Padial Guerchoux, Anita y Manuel Vázquez-Bigi

$1991 \quad$ Quiche Vinak. Tragedia. Nueva versión española y estudio histórico-literario del llamado "Rabinal-Achí". México: Fondo de Cultura Económica.

Said, Edward

1994 Orientalismo. Barcelona: Prodhufi.

Sartre, Jean Paul

2006 "Lo Imaginario (fragmento)", Blog Descontexto.

$<$ http://descontexto.blogspot.com/2006/12/lo-imaginario-de-jean-paul-sartre.html > [Consultada el 1 de diciembre de 2012.]

Sengher, Ann

1975 Tráfico. Barcelona: Bruguera.

Stephens, John

1969 Incidents of Travel in Central America, Chiapas and Yucatán. Nueva York: Dover. 2 volúmenes.

Weinberger, Eliot (ed.)

1992 Una antología de la poesía norteamericana desde 1950. México: Ediciones de El Equilibrista. 
